\title{
Does Improved Local Supply of Schooling Enhance Intergenerational Mobility in Education? Evidence from Jordan ${ }^{*}$
}

\author{
Ragui Assaad $^{\dagger}$
}

\author{
Mohamed Saleh ${ }^{\ddagger}$
}

\begin{abstract}
This paper examines the effect of increased local supply of public schools on intergenerational mobility in education in Jordan. We use a unique data set that links individual data on own schooling and parents' schooling for adults, from a household survey, with the supply of schools in the sub-district of birth at the time the individual was of age to enroll, from a school census. We identify the effect by exploiting the variation in the supply of basic and secondary public schools across cohorts and sub-districts of birth in Jordan, controlling for year and sub-district of birth fixed effects and interactions of governorate and year of birth fixed effects. Our findings show that the local availability of basic public schools does in fact increase intergenerational mobility in education. For instance, a one standard deviation increase in the supply of basic public schools per 1,000 people reduces the father-son and mother-son associations of schooling by 18-20 percent and the father-daughter and mother-daughter associations by 33-44 percent. However, an increase in the local supply of secondary public schools does not seem to have an effect on the intergenerational mobility in education.
\end{abstract}

JEL Classification: I24, I28

Keywords: Supply of schooling, education, intergenerational mobility, inequality of opportunity, Middle East

\footnotetext{
* This paper was supported by a grant from the Economic Research Forum as part of the research project on Inequality of Opportunity and Inequality of Outcomes in the Arab Region. Saleh thanks Norhan Muhab for her excellent research assistance and gratefully acknowledges the support from the ANR-Labex IAST.

${ }^{\dagger}$ Corresponding author. Humphrey Institute of Public Affairs, University of Minnesota, 301 19th Ave. S., Minneapolis, MN 55455; E-mail: assaad@umn.edu.

${ }^{\ddagger}$ Toulouse School of Economics and Institute for Advanced Study in Toulouse; E-mail: mohamed.saleh@tse-fr.eu.
} 


\section{Introduction}

Over the past three or four decades, the Arab world has experienced a massive expansion in educational attainment. According to the Barro and Lee educational attainment data set, 7 out of the top 20 countries in terms of increase in number of years of schooling from 1980 to 2010 were Arab countries (Barro and Lee 2013). ${ }^{4}$ Jordan, the subject of this paper, had the seventh highest increase in educational attainment in the world, with an increase of about 5 years in the average years of schooling over the period. This increase is widely believed to be attributable to a massive public investment in the supply of schooling in the post-independence period in the context of a state-led development model, which virtually guaranteed employment in the public sector for graduates (Assaad 2014; Saleh 2016). The rapid increase in educational attainment has continued unabated despite the fall in returns to education that accompanied the demise in the state-led model and its employment guarantee schemes (Pritchett 2001). A slew of recent literature on the drivers of the Arab Spring protests, some of which occurred in Jordan, has identified the low economic returns to this massive increase in education as the single most important cause of the uprisings (Goldstone 2011; Campante and Chor 2012a, 2012b, 2014; Sanborn and Thyne 2014).

Another way to view the connection between low return to education and youth frustrations is that the rapid intergenerational mobility in education has failed to yield similar mobility in either income or social status. This delinking between educational and occupational mobility has been documented for Egypt by Binzel and Carvalho (2013). While there is no similar work on

\footnotetext{
${ }^{4}$ This is based on version 2.0 of the Barro-Lee data set for educational attainment among the total population 15 and older.
} 
Jordan, we contribute to this agenda by documenting the first step in this process, which is the link between public investment in schooling and the educational mobility across generations.

Although Jordan shared the general drive toward increasing educational attainment with much of the Arab world, it faced particular challenges of refugee absorption and nation building due to its history of welcoming large inflows of Palestinian refugees in the aftermath of the 1948 and 1967 Arab-Israeli wars and the First Gulf War of 1991. While Palestinians, like other diaspora populations, have traditionally favored investments in human capital over physical capital (Badran 1980; Ayal and Chiswisk 1983), the arrival of large numbers of refugees in short order must have imposed severe challenges on the capacity of the Jordanian state to respond. This need was partially met by the intervention of United Nations Relief and Works Agency (UNRWA), which was tasked with providing basic schooling for Palestinians classified as refugees. However, the additional intervention of the Jordanian state was essential to meet the schooling needs of the large number of Palestinians without official refugee status and at the secondary level for all (Abu-Lughod 1973). Jordan had to face the additional challenge of nation-building and the construction of a collective identity in a society fragmented along urban Palestinian and bedouin Jordanian lines; a task that is often entrusted to the education system (Gellner 1983; Frisch 2002; Lucas 2008).This paper examines the question of whether an increase in the local supply of public schools reduces the intergenerational persistence of educational attainment in Jordan. Given the challenge of absorbing successive waves of refugees and of nation building in an ethnically fragmented society, it is important to ascertain the extent to which Jordan's education policies have managed to provide more equal access to education for all its citizens. The question is also relevant to socially conservative settings, such as Jordan's, 
where children's educational attainment, especially that of girls, is constrained by the limited local supply of schools, as girls are often not allowed to enroll in a distant school.

We employ a unique data source from Jordan, the 2010 Jordan Labor Market Panel Survey (JLMPS 2010), which includes information on parents' schooling for every adult in the sample, along with the 2010 School Census produced by the Jordanian Ministry of Education (Hashemite Kingdom of Jordan, 2010). The school census provides the sub-district, type, and date of establishment of every school in Jordan, allowing us to measure the local supply of each type of schools in each sub-district in every year (under the presumption that there were no significant school closures or changes in type over time, which is likely the case). The exposure of an individual in the JLMPS 2010 sample to the supply of public schooling is then determined by the number of sex-appropriate basic (or secondary) public schools (per 1,000 individuals) that were available to them in their sub-district of birth at the time they were of age to enroll in that school level (6 years of age for basic and 15 years for secondary). The richness of the data set makes it the first in the Middle East to allow such a study.

We employ a standard difference-in-differences approach to disentangle the impact of the expansion of local public schooling on the correlation between a child's educational attainment and that of his/her parents. In particular, we exploit the variation in the supply of public schools across cohorts and sub-districts of birth, and allow the effect of this variable to vary by parent's schooling, where we control for both sub-district of birth and year of birth fixed effects. Our empirical strategy is similar to that used in Duflo (2001) who looked at the impact of increased school supply on educational attainment. We add parents' schooling as an additional regressor 
and interact it with the local supply of public schools to obtain the effect of public school supply on the coefficient of intergenerational persistence of educational attainment. ${ }^{5}$

One fundamental limitation of our empirical strategy though is that, unlike in Duflo (2001) or Meghir and Palme (2005), the growth of the local supply of public schools in Jordan was gradual rather than an abrupt change due to a specific reform. It is thus likely to have been affected by both supply-side and demand-side factors, making it challenging to disentangle the causal impact of local school supply. While we are unable to rule out this limitation, we argue that the results are likely causal for three reasons. First, the allocation of public schools in Jordan is highly centralized and was essentially aimed at reducing initial inequality in education across sub-districts. We support this argument by analyzing the association between the growth in the supply of schooling at the sub-district level with initial local educational and occupational characteristics. Second, we include a full set of interactions of governorate of birth and year of birth fixed effects which control for time-varying characteristics of governorates that may drive differences between sub-districts in the growth of local school supply and educational attainment. This should arguably account for most of the time-varying spatial heterogeneity in Jordan. Third, since one may be concerned about the selected migration of parents across sub-districts, which is potentially induced by the differential growth of the local supply of schools, we add a robustness check where we estimate the results excluding movers, i.e. children who changed their subdistrict of residence between age 0 and 15 (we are unable though to identify children whose parents moved before they were born). The results remain unchanged.

\footnotetext{
${ }^{5}$ Potential endogeneity of parent's schooling is not a concern here because we are not interested in identifying the causal impact of parent's schooling on child's schooling but rather the effect of the expansion of public schooling on the correlation between parent's schooling and child's schooling.
} 
Our findings indicate that the supply of public basic schools does significantly increase the intergenerational mobility of education in Jordan, especially among females, but the supply of secondary schools does not have an effect. Increasing the supply of sex-appropriate basic schools per 1,000 people by one standard deviation ( 0.19 for males and 0.13 for females) reduces the father-son and mother-son intergenerational persistence coefficients by 18-20 percent, and reduces the father-daughter and mother-daughter coefficients by 44 percent and 33 percent, respectively. These effects are robust to including governorate of birth by year of birth fixed effects. In contrast, an increase in the supply of secondary schools per 1,000 has no significant effect on the intergenerational persistence coefficients of males even when we restrict the sample to those with at least basic education (who should benefit at least in principle form secondary schools). For females, an increase in secondary schools is even associated with an increase in the coefficient of intergenerational persistence in the full sample, but this anomalous correlation goes away if we restrict the sample to females with at least basic education.

Overall, the findings suggest that the local supply of basic schools is a binding constraint on both the educational attainment and the intergenerational educational mobility of Jordanian males and more so among females. On the other hand, the local supply of secondary schools does not seem to be a binding constraint for either males or females with respect to either educational attainment or educational mobility across generations.

The paper is linked to the vast literature on intergenerational mobility of educational attainment (Behrman et al. 1999; Salehi-Isfahani 2001; Dahan and Gaviria 2001; Daouli, Demoussis, and Giannakopoulos 2010; Checchi, Fiorio, and Leonardi 2013). One line of this literature focused on examining the impact of specific policies on educational mobility. For example, Behrman and Wolfe (1987) examined the relative impact of parental schooling versus 
school supply on child’s educational attainment. Checchi, Ichino, and Rustichini (1999) and Davies, Zhang, and Zeng (2005) studied the effect of public versus private educational systems on mobility. Schütz, Ursprung, and Wößmann (2008) explored the impact of a number of educational policies on an index of equality of educational opportunity across countries. Checchi and Flabbi (2013) studied the effect of secondary schooling tracking systems on mobility. This paper makes two contributions to this literature. First, it extends the analysis in Behrman and Wolfe (1987) by examining the impact of the expansion of the local supply of public schools on educational mobility. As far as we know, this question has not been studied before. This policy is of primary relevance to the experiences of developing countries where public schooling was the only realistic means to eradicate illiteracy among the masses. Second, while previous mobility studies in the developing world examined outcomes for children who are co-resident with their parents, in order to be able to make use of standard surveys that lack longitudinal or retrospective data on parental characteristics, the JLPMS allows us to improve on these studies by including information on parental characteristics of all adults in the sample.

The rest of the paper is organized as follows: Section II provides a background on the evolution of educational attainment and the expansion of public schooling in Jordan. Section III describes the conceptual framework that motivates the empirical analysis. Section IV includes a description of the data. Section $\mathrm{V}$ characterizes the trend across cohorts of intergenerational educational persistence in Jordan. Section VI describes our identification strategy. Section VII presents our findings with regard to the effect of increasing the local supply of public schools on intergenerational educational mobility. We discuss several robustness checks in Section VIII. Finally, section IX concludes. 


\section{Jordan's Growth of Educational Attainment and Public School Supply}

Educational attainment in Jordan witnessed dramatic growth in the second half of the twentieth century. Figure I depicts the evolution of the average years of schooling of males and females by year of birth based on data from JLMPS $2010 .{ }^{6}$ The figure clearly depicts the rapid increase in educational attainment across cohorts for both males and females. For males, the increase occurred earlier, with their mean years of schooling rising from under six years for the 1940 birth cohort to ten years for the 1955 cohort. It then stagnated at about 11 years for cohorts born between 1960 and 1975, only to start rising again for younger cohorts. The increase in female mean years of schooling occurred later and was more sustained. The mean years of schooling starts as low as fewer than two years for the 1940 cohort and rises rapidly to about ten years for the 1965 cohort. Although the rate of increase of female schooling slows after that, the mean years of schooling for women exceeds that of their male counterparts for the youngest cohort born between 1975 and 1985.

To investigate whether this dramatic increase in educational attainment corresponds to the expansion of public schools in the country, we depict in panels (A) and (B) of Figure II the average number of basic and secondary public schools per 1,000 individuals in sub-district of birth for the JLMPS 2010 sample. The data on the number of public schools is obtained from the school census carried out in 2010 by the Jordanian Ministry of Education. ${ }^{7}$ We focus on public

\footnotetext{
${ }^{6}$ Mean years of schooling for older cohorts may be biased upward due to selectivity resulting from the likely higher mortality of less educated individuals.

${ }^{7}$ Since these figures are based exclusively on surviving schools in 2010, they ignore school closures and school conversions from one type of school to another. Basic schools currently go from first to tenth grade. Before 1994, they were subdivided into primary schools (going from first to sixth grade) and preparatory schools (going from seventh to ninth grade).
} 
schools because they enroll the vast majority of students in Jordan. ${ }^{8}$ One can clearly see from panel (A) of Figure II that the growth in the supply of public basic schools started to take off for the cohort born in 1950 and continued at a rapid pace through the mid-1970s cohort. Initially more boys' schools were being built, corresponding to the early school acquisition of Jordanian males. The supply of girls' and mixed schools was also rising for the cohorts born in 1950 onward, but by the 1965 cohort, there appears to have been a concerted effort to dramatically increase the supply of mixed schools. This corresponds roughly to the cohort of Jordanian women that have experienced the largest increase in schooling relative to previous cohorts. Indeed, an examination of the 2010 school census data reveals that the majority of students in mixed schools are girls at both the basic and secondary levels (70 percent and 86.5 percent respectively), which suggests that the rapid increase in schooling for females was primarily accounted for by the growth in mixed schools. Panel (B) of Figure II depicts the growth in the supply of public secondary schools. The growth in the supply of boys', girls', and mixed secondary schools was steady across the observed birth cohorts. The number of boys' secondary schools being equal to the number of girls' and mixed secondary schools combined, bearing in mind the fact that mixed secondary schools were de facto girls' schools.

Since our empirical analysis is contingent on the exogeneity of the growth in the supply of schools at the local level, controlling for governorate-level time-varying heterogeneity, we conduct an analysis of its association with the initial observable characteristics of the local populations. Because we do not have reliable historical data on the characteristics of sub-districts

\footnotetext{
${ }^{8}$ Data from the JLMPS 2010 indicates that 94.1 percent of Jordanians between the ages of 25 and 35 who went to basic schools within Jordan were enrolled in public schools run by the Ministry of Education or some other Ministry of the Jordanian government or by the UN Relief and Works Agency for Palestinian Refugees in the Near East (UNRWA), which provides basic schooling to Palestinian refugees in Jordan. For purposes of our analysis, UNRWA schools are considered public schools. The proportion of secondary school students in 2010 enrolled in public schools is 94.7 percent.
} 
in Jordan, we use the characteristics of those 60 and older from the 2004 population census (who have presumably obtained their education prior to the period under consideration). ${ }^{9}$ In particular, we regress the average annual growth of basic public schools from 1946 to 1991 (the period under consideration in our main empirical analysis) at the sub-district level on: (i) the percentage with primary but less than secondary education, (ii) the percentage with secondary but less than university, (iii) the percentage with university and above, (iv) the percentage of professional workers (managers, professionals and associated professionals) in total employment, (v) the percentage born outside Jordan, (vi) the number of schools in 1946, and (vii) the logarithm of the total population in 2004. We repeat the exercise for the growth of secondary schools, but in this case for the 1955-2000 period, which is the relevant period given the cohort we examine in our empirical analysis. All regressions include governorate fixed effects to control for time-invariant unobserved governorate-level characteristics. Regressions are run separately for girls', boys', mixed, and all schools.

The results of these regressions are shown in Table I. Overall the regressions suggest that the most important determinant of the growth in the supply of schooling is the initial level of schooling, with initially deprived sub-districts having, on average, a higher growth rate. In a few of the regressions, the educational level of the $60+$ population is negatively correlated to the growth in school supply. This also suggests that the expansion of schooling was aimed to reduce educational disparities. The growth in supply of schooling is also positively correlated with the 2004 population, suggesting that the government was supplying schools to growing jurisdictions. There is no evidence from these regressions that sub-districts with initially more educated

\footnotetext{
${ }^{9}$ For occupational characteristics, we use the population 50 and older in 2004 because we only have occupations for those who are still employed. This exercise also assumes that the survivorship bias is the same across sub-districts within a governorate.
} 
populations, ones with higher average socio-economic status or higher proportions of migrants/refugees demanded and received higher growth in school supply, supporting our contention that the growth was primarily supply driven.

\section{Conceptual Framework}

The classic model of intergenerational mobility attributes the transmission of human capital from parent to child to either inheritance of parental endowment (both genetic traits and culture) or parental investment in child's human capital (Becker and Tomes 1979; Solon 2004). In this model, the steady-state intergenerational association between parent's income and child's income depends positively on two factors: (a) the elasticity of child's income with respect to parental investment in child's human capital, where richer parents invest more in their child's human capital hence making their children richer, and (b) the heritability coefficient of parental genetic and cultural endowment, where richer parents tend to have greater endowment that is passed on to their offspring.

The impact of the provision of public schools on the intergenerational association of human capital could be analyzed using Solon's (2004) model, which adapts Becker and Tomes (1979) model by including public investment into the production function of child's human capital. In this model, the steady-state intergenerational correlation of income depends negatively on a third factor besides the two factors described above, (c) the degree of "progressivity" of public investment in child's human capital. Progressive public investment in child's human capital means that the ratio, and not necessarily the absolute value, of public investment to parental after-tax income decreases with parental income. The more progressive the governmental policy is, the faster this ratio declines with parental income and the less the intergenerational correlation of income is. 
One could think of Jordan's growth of local supply of public basic and secondary schools as a progressive public investment in human capital that increases the human capital production for children of marginal parents in terms of income and educational attainment. Those are parents who would have chosen higher investment in the human capital of their offspring, but were constrained by the limited supply of schools in their sub-districts of residence and could not afford to send their children to more distant schools outside their jurisdiction or to provide them with home schooling. However, the increase in public schools is expected to have less of an effect on richer or more educated parents, who are expected to provide education to their children regardless of the availability of schools in their sub-districts either by sending their children to distant schools or through home schooling. On average though we expect the increase in the local supply of public schools to reduce the intergenerational correlation of educational attainment or enhance intergenerational educational mobility.

\section{Data}

We employ two new and unique data sources in the empirical analysis. First, the Jordan Labor Market Panel Survey of 2010, carried out by the Economic Research Forum in cooperation with the Jordanian Department of Statistics, is a rich source of information on all aspects of the Jordanian labor market (JLMPS 2010). Most importantly for our purposes is the fact that the survey provides individual-level data on own schooling and parents' schooling for all adults in the sample, which is quite rare in household surveys from developing countries. We also observe the actual years of schooling completed and not only the highest educational degree attained, which allow us to observe the schooling variable with precision.

Second, each individual in the JLMPS restricted sample is matched to the 2010 Jordanian school census. The matching process determines for each individual the number of sex- 
appropriate public basic and secondary schools per 1,000 individuals available in the individual's sub-district of birth when the individual was of age to accede to this educational level (6 years of age for the basic level and 15 years of age for the secondary level). ${ }^{10} \mathrm{~A}$ school is considered sexappropriate for a female if it is a girls' or a mixed school and for a male if it is a boys' or mixed school. We also perform the empirical analysis by entering boys', girls', and mixed schools separately. ${ }^{11}$ Measuring the local supply of public schools at the sub-district of birth of the individual (i.e. the child) mitigates potential endogeneity originating from parents who had a higher taste for schooling moving to sub-districts where public schooling was more abundant when their child was of school age although we are unable to rule out that parents might have moved across sub-districts prior to the birth of their child.

We restrict the JLMPS sample, after matching it to the 2010 school census, to individuals born in Jordan who are aged 25 to 70 in 2010 and who have non-missing information on age, sub-district of birth, years of schooling, father’s schooling, mother's schooling, and local supply of schools in sub-district of birth. ${ }^{12}$ These exclusions resulted in a sample of 4,139 males and 4,131 females, which we refer to as the male and female full samples, respectively.

The summary statistics for the full sample of males and females are shown in Table II. Male and female samples have similar statistics for most variables, except that males have slightly higher years of schooling on average (10.8 vs. 9.8 years). Most of the local supply of public

\footnotetext{
${ }^{10}$ Because of the absence of annual estimates of sub-district populations, the population used to normalize the supply of schooling at the sub-district level is the 2004 population of the sub-district. There are 86 sub-districts in Jordan. If sub-district populations are growing at different rates, this could introduce some measurement error of the true supply of schooling available to different cohorts.

${ }^{11}$ Secondary schools include both general and vocational secondary schools. Public schools include schools under the jurisdiction of: (i) Ministry of Education, (ii) Ministry of Higher Education, (iii) Ministry of Defense, (iv) Ministry of Social Development, (v) Ministry of Religious Endowments (Awqaf), and (vi) UNRWA.

${ }^{12}$ The original sample size of all individuals who are aged 25 to 70 years in 2010 and are born in Jordan is 8,312 observations. The sample restrictions on the missing values result in the exclusion of 34 observations (missing age), 1 observation (missing father's schooling), and 7 observations (missing mother’s schooling).
} 
basic schools comes from mixed and boys' schools; the average supply of each is about three times the supply of girls' schools. Similarly, secondary schools are mostly boys' schools where the average supply of boys' secondary schools is equal to the supply of mixed and girls' secondary schools combined. But as we discussed earlier, examining the sex composition of mixed schools in 2010 (results not shown) reveals that girls constitute 70 percent of mixed basic schools and 86.5 percent of mixed secondary schools. It thus appears that mixed schools are de facto girls' schools in their most part, and they thus account for the higher educational attainment among females.

\section{Intergenerational Educational Mobility in Jordan: Time Trend}

Before getting into the effect of the growth of the local supply of public schools on intergenerational educational mobility, we conduct a few regressions to characterize the rate at which the intergenerational educational correlation coefficient has been changing across cohorts for the four different parent-child combinations (father/son, mother/son, father/daughter, and mother/daughter). We estimate the following OLS regression:

childeduc $_{i j}$

$=\beta_{11}$ parenteduc $_{i j}+\beta_{12}$ agedev $_{i j}+\beta_{13}\left(\frac{\operatorname{agedev}_{i j}^{2}}{100}\right)+\beta_{14}\left(\right.$ parenteduc $\left._{i j} \times \operatorname{agedev}_{i j}\right)$

$+\beta_{15}\left(\right.$ parenteduc $\left._{i j} \times \frac{\text { agedev }_{i j}^{2}}{100}\right)+\alpha_{j}+\varepsilon_{1 i j}$

Where the outcome variable, childeduc, is years of schooling of child $i$ born in sub-district $j$ and parenteduc is parent's years of schooling. In order to depict the change in intergenerational educational mobility across cohorts of birth, we control for agedev, or the difference between individual's age and the average age in the sample, and its square divided by 
100, and we interact each with parent's schooling. Finally, we include $\alpha_{j}$, a full set of sub-district of birth fixed effects to capture mean differences in child's schooling across sub-districts; $\varepsilon_{1 i j}$ is an error term.

The results are shown in Table III. Model 1 shows that the average intergenerational correlation coefficient for all age groups of individuals 25 to 70 in 2010 is higher between mothers and their children than between fathers and their children and it is also slightly higher for females than it is for males, with both parents. It also shows that years of schooling decrease at an increasing rate with age, capturing the rapid increase of educational attainment among increasingly younger cohorts in Jordan (shown in Figure I). Model 2 shows that intergenerational persistence also increases at an increasing rate with age in Jordan, meaning that intergenerational mobility in education has risen rapidly over time in Jordan. The trend of the intergenerational persistence coefficient estimated in Model 2 for the various parent-child combinations is illustrated graphically in Figure III. For instance, the correlation between the educational attainment of a 50 year-old woman in Jordan with that of her mother was 0.7 , while that of a 25 year-old woman was only 0.15. As discussed above, the coefficient of intergenerational persistence tends to be larger for both sexes of children with their mothers. It also tends to be larger for females with both their parents, but only for those above age 30-35. This implies that the intergenerational persistence coefficient has fallen more sharply across cohorts for women in Jordan, as women began acquiring education in large numbers in recent years.

\section{Empirical Strategy}

We now come to the main question motivating this paper, namely the effect of the local supply of public schools on the intergenerational transmission of educational attainment. We employ a difference-in-differences methodology that exploits the variation across years and sub- 
districts of birth in the local supply of public basic and secondary schools. Specifically, we estimate the following OLS regression:

childeduc $_{i j k t}$

$=\beta_{21}$ parenteduc $_{i j k t}+\beta_{22}$ basicschool $_{j k t}+\beta_{23}$ secschool $_{j k t}$

$+\beta_{24}\left(\right.$ parenteduc $_{i j k t} \times$ basicschool $\left._{j k t}\right)+\beta_{25}\left(\right.$ parenteduc $_{i j t} \times$ secschool $\left._{j k t}\right)+\alpha_{j}+\gamma_{t}$

$+\delta_{k} * \gamma_{t}+\varepsilon_{2 i j k t}$

Where the outcome variable, childeduc, is years of schooling of child $i$ born in sub-district $j$ in governorate $k$ in year $t$; basicschool and secschool are the number of sex-appropriate public basic and secondary schools per 1,000 individuals that were available in the child's subdistrict of birth in the year when the child was of age to accede to this educational level (6 years of age for the basic level and 15 years of age for the secondary level); number of sex-appropriate schools is defined as the sum of boys' and mixed schools for males and the sum of girls' and mixed schools for females, but we also estimate the equation where we break down schools by gender (boys, girls, and mixed schools); $\varepsilon_{2 i j k t}$ is an error term. All standard errors are clustered at the sub-district of birth level.

There are three sets of fixed effects in this equation. First, $\alpha_{j}$ are a full set of sub-district of birth fixed effects to control for unobserved time-invariant characteristics of sub-districts that may affect a child's educational attainment, $\gamma_{t}$ are a full set of year of birth fixed effects to control for unobserved aggregate shocks that may have affected children's educational attainment in all sub-districts in a given year, and $\delta_{k} * \gamma_{t}$ are a full set of interactions of governorate of birth and year of birth fixed effects to control for unobserved shocks that may have affected children's educational attainment in sub-districts within a given governorate in a 
certain year. We are interested in the two parameters, $\beta_{24}$ and $\beta_{25}$, which capture the impact on intergenerational educational transmission of the local supply of public basic and secondary schools respectively. We expect each of the two coefficients to be negative, implying a positive impact of the supply of public schools on intergenerational educational mobility.

The identifying assumption underlying this estimation strategy is that the variation in the local supply of public schools across years and sub-districts of birth is uncorrelated with unobservable within-governorate time-varying characteristics of sub-districts that may drive both the local supply of public schools and intergenerational educational mobility. A confounding factor that could violate this assumption is that, within a given governorate, sub-districts with a rising demand for education over time (perhaps because of economic development) may tend to obtain differentially more public schools and also have higher intergenerational educational mobility compared to other sub-districts even in the absence of a causal relationship between the supply of public schools and intergenerational educational mobility.

In order to rule out these confounding factors and argue that the impact of the local supply of schools on intergenerational educational mobility is causal, we ideally want to observe, as in Card and Krueger (1992), Duflo (2001), and Meghir and Palme (2005), an abrupt change in the local supply of public schools for exogenous reasons (e.g. educational reform or school construction program) that are not driven by the preferences of the local population or other demand-side factors. However, as Figure II demonstrates, the growth of the supply of public schools in Jordan was gradual, making it challenging to disentangle its causal impact on intergenerational educational mobility, because it could have been driven by both supply and demand factors. While, in the absence of a historical natural experiment, we are unable to rule out this fundamental limitation of the empirical strategy, there are three reasons that make us 
more confident in our results. First, the decision-making about the allocation of public schools in Jordan is highly centralized in the Ministry of Education and, as we have documented in Table I, the growth of the local supply of public schools seems to have been aimed at reducing educational inequalities across sub-districts within governorates. Second, including a full set of interactions of governorate and year of birth fixed effects allows us to control for unobserved time-varying characteristics at the governorate-level, and it is likely that most of the unobserved geographic heterogeneity in the allocation of public schools and intergenerational educational mobility in Jordan is between rather than within governorates. Third, we carried out a number of robustness checks in order to mitigate the concerns about migration across sub-districts, the geographic variation in receiving Palestinian refugees, and the serial correlation among individuals in our sample who belong to the same household. The results remain unchanged.

\section{Results}

The central results of the paper are shown in Table IV, which includes the estimation results of equation (2) for each of the four parent-child combinations. For each combination, we estimate the equation using the total supply of sex-appropriate public basic and secondary schools and the school supply broken down by school gender. We estimate equation (2) without and with interactions of governorate and year of birth fixed effects.

We start by discussing the results for males shown in Panel (A) of Table IV. We first note that, among sons of uneducated parents, the baseline impact of the local supply of public schools on the school attainment of males is positive and statistically significant at both the basic and secondary levels. An increase of one standard deviation in male-appropriate basic schools per 1,000 people $(\sim 0.19)$ is associated with $0.57-0.60$ additional years of schooling for males, whereas an increase of one standard deviation in male-appropriate secondary schools per 1,000 
people ( 0.19) is associated with 0.85-0.94 additional years of schooling. The baseline effect is attributable to mixed schools in the case of basic schools and to both boys' and mixed schools in the case of secondary schools (see column 2). However, the baseline effect of basic schools becomes small and statistically insignificant when we control for governorate by year of birth fixed effects (column 4), suggesting that it is impossible to disentangle the effect from unobserved time-varying variables at the governorate level. The baseline coefficient on secondary schools (in particular, mixed schools) retains its magnitude and statistical significance though.

As shown in column 1 and 5 of panel (A) of Table IV, the interaction term of the local supply of schools with parental schooling has the expected negative effect for basic schools, indicating that the effect of basic schools is smaller for males whose parents have more years of schooling, but is insignificant for secondary schools, which means that the impact of secondary schools does not vary with parental schooling. This suggests that the local supply of basic schools increases intergenerational educational mobility for males but the local supply of secondary schools does not. In terms of magnitude, a one standard deviation increase in basic schools per 1,000 results in a relative reduction in the coefficient of intergenerational educational persistence of 18 -20 percent $[=(0.19 * 0.275) / 0.284]$ for both parents. When we control for governorate by year of birth fixed effects (columns 3 and 7), the impact of basic schools on intergenerational educational persistence retains its magnitude, although it loses its statistical significance in the case of mothers.

Moving on to the results for females shown in Panel (B) of Table IV, we find that the baseline effect of the local supply of basic schools on educational attainment among daughters of uneducated parents is positive, as expected, and larger in magnitude than that for males (columns 
$1,3,5$, and 7). As in the case of males, the positive effect of basic schools on attainment is attributable to the growth of mixed schools (columns 2, 4, 6, and 8). A one standard deviation increase in the local supply of female-appropriate basic schools per 1,000 population $(\sim 0.13)$ results in an increase of 1.07-1.23 years of schooling for females. In contrast, the baseline effect of the local supply of secondary schools on attainment among daughters of uneducated parents is statistically insignificant. While controlling for governorate by year of birth fixed effects (columns 3 and 7) reduces the baseline effect of basic schools in half, it remains statistically significant because of its large magnitude, unlike the case of males.

The negative sign on the interaction term of the supply of basic schools and parental schooling indicates that the supply of basic schools significantly reduces the coefficient of intergenerational persistence for females as well, and the effects are much stronger than for males (columns 1 and 5). The coefficient falls by 44 percent and 33 percent for a one standard deviation increase in female-appropriate basic schools per 1,000 individuals for fathers and mothers, respectively, with both of these effects significant at the 1 percent level. Unexpectedly, the supply of secondary schools appears to increase the coefficient of intergenerational persistence for females, an issue we return to below. When we include governorate by year of birth fixed effects (columns 3 and 7), the effects of basic schools on the coefficient of intergenerational persistence are still negative and slightly smaller in magnitude but are statistically significant. The positive effects of secondary schools are smaller but still significant for fathers and insignificant for mothers.

In order to explore the impact of the local supply of secondary schools on mobility in more depth, we note that those schools are likely to affect individuals with at least basic education but not below. We thus re-estimated equation (2) on the restricted sample of individuals who have at 
least basic schooling. The results of this exercise are shown in Table V. We find that the baseline effects of secondary schools mostly lose their statistical significance for both males and females. More importantly, secondary schools do not seem to have an effect on intergenerational educational mobility for either group. The anomalous finding in Table IV of a positive correlation between the local supply of secondary schools and the coefficient of intergenerational persistence in educational attainment for females becomes much smaller in magnitude and loses its statistical significance in the restricted sample of females with at least basic schooling. This indicates that the positive correlation in Table IV is likely a statistical artifact.

To summarize, our main finding is that the local supply of public basic schools appears to be a binding constraint on the educational attainment of both males and females. Thus, loosening this constraint raises attainment levels differentially more for individuals whose parents have lower educational levels. As such it increases intergenerational mobility in education. While these effects hold for both males and females, they are larger in magnitude for females, suggesting that the local supply of public basic schools is more of a binding constraint for females than for males.

The results on the supply of secondary schools suggest that they are less of a binding constraint on either group and have no statistically significant effect on educational mobility. For males, we find that the local supply of secondary schooling significantly raises attainment levels on average, but not differentially by parents' schooling. This suggests that the supply of secondary schooling is a binding constraint on attainment for males, but is equally binding regardless of the level of parental education. In the case of females, the supply of secondary schools does not appear to be a binding constraint since higher local supply does not appear to raise educational attainment, and secondary schools do not seem to matter for educational 
mobility either. This suggests that from a policy perspective, increasing the local supply of public basic schools seems to matter more for enhancing the equality of opportunity across all individuals than investing in public secondary schools.

\section{Robustness Checks}

We conduct several robustness checks in order to address various concerns about our baseline results. Due to space constraints, the results of this section are relegated to an online appendix. First, one may be concerned that we observe the local supply of schools in the individual's sub-district of birth and not in the sub-district of parent's residence when the individual was of age to access school. In particular, it is possible that parents moved with their children between the child's birth and the year they entered basic or secondary schools. Fortunately though, the JLMPS 2010 sample allows us to identify "movers," those individuals who changed their sub-district of residence between age 0 and 15 . We thus exclude these individuals from the sample and re-estimate equation (2) for both males and females. ${ }^{13}$ The results are shown in Table A1 in the online appendix. We find that the baseline effects of basic schools on educational attainment and their effects on mobility are stronger and often more significant than those estimated in Table IV for both males and females.

A second concern is that Jordan received a large influx of Palestinian refugees in the aftermath of the 1967 Arab-Israeli War. While refugees benefited from the UNRWA basic schools, their educational attainment and intergenerational educational mobility were perhaps subject to a different set of constraints than those facing other Jordanians. We thus attempt to exclude Palestinian refugees from the sample as a robustness check. The JLMPS 2010 does not

\footnotetext{
${ }^{13}$ In doing so, we exclude 381 "movers" among males and 371 "movers" among females, or roughly 9 percent of the original samples.
} 
allow us to directly identify Palestinian refugees who are now mostly Jordanian citizens, and so we had to employ two alternative indirect methods to identify individuals who are likely to be Palestinian refugees. In Method I we exclude individuals born in sub-districts where the percentage of individuals who were ever enrolled (or are currently enrolled) in an UNRWA school exceeds 10 percent out of all individuals below 36 years of age in the sample. In Method II we exclude individuals born in sub-districts where the percentage of UNRWA schools exceeds 10 percent of the total number of schools. The results for the restricted sample according to both methods are shown in Tables A2 and A3 respectively. Overall, the results remain unchanged from those in Table IV.

A third concern is that the samples of males and females that are employed in the analysis may include adult siblings who belong to the same household. This could introduce intrahousehold serial correlation among these observations. Thus as a robustness check we restrict the sample to males and females who are household heads or their spouses, hence excluding adult siblings. This reduces our male sample from 4,139 to 3,271 and our female sample from 4,131 to 3,333. The results are shows in Table A4 and are similar to those in Table IV.

Fourth, in an attempt to understand why the effect of the local supply of public schools varies by the level of parental education for basic schools but not for secondary schools, we examined whether parents have an outside option when public schools are absent. In particular, if private schools are available in the vicinity, educated parents are more likely to avail themselves of them, resulting in a less binding public school supply constraint at higher levels of parental education. However, if private schools are not available, the education of the children of even educated parents will be constrained by the absence of public schools, making the local supply of public schools equally binding regardless of parental education. Accordingly, we examined the 
supply of private basic and secondary schools at the sub-district level in the 2010 Jordanian school census. We found that private basic schools are relatively spread out across sub-districts whereas private secondary schools are mostly concentrated in a handful of districts. For example, 79 percent of all sub-districts in 2010 had no private secondary schools and therefore no outside option for parents, as compared to only 45 percent of sub-districts not having private basic schools. Thus an increase in the supply of public secondary schools relieves a constraint for everyone, while an increase in the supply of public basic schools provides relatively more relief for less educated parents.

Finally, we conducted two sets of regressions to further examine the robustness of our results. In particular, we were concerned about possible collinearity between the local supply of basic and secondary schools, so we ran regressions with one or the other type of school supply. For both males and females, when only the supply of basic schools was retained there was no appreciable change in the baseline effect or in its interaction with parental schooling. When the supply of secondary schooling was retained, the positive baseline effect for males was unchanged and the interaction remained small and insignificant. For females, the main effect of secondary schools remained insignificant and the interaction remained positive and significant at the 5 percent level for the father-daughter regression, but not for the mother-daughter regression. Thus the results remain essentially unchanged.

\section{Conclusions}

This paper investigated the extent to which intergenerational mobility in education in Jordan was enhanced by government policies to increase the supply of public basic and secondary schools. Our identification strategy relied on exploiting the variation in school supply across subdistricts and cohorts of birth to identify the effect of school supply on the coefficient of 
intergenerational persistence in educational attainment, where we control for year of birth and sub-district of birth fixed effects. Importantly, we also control for a full set of interactions of year of birth and governorate of birth fixed effects. These fixed effects allow us to control for the time-varying characteristics of the governorate of birth that may drive both local public school supply and educational attainment for a given year of birth.

By first analyzing intergenerational mobility across cohorts we establish that mobility has increased significantly in Jordan over time, and more so for women than for men. We also find that the school attainment of the children of uneducated parents is significantly enhanced by the increased supply of basic schools (the baseline effect), with the effect being larger for females than for males. These effects are primarily due to the availability of mixed schools for both males and females.

With regard to our main research question regarding the effect of school supply on intergenerational mobility in education, we find that an increase in the local supply of basic schools reduces intergenerational persistence in education for women three times more than it does for men. A one standard deviation increase in basic schools per 1,000 people reduces the coefficient of intergenerational persistence by at least one third for women and by one fifth for men. Both effects are robust to controlling for interactions of year and governorate of birth fixed effects. The fact that the effect of the local supply of basic schools is larger for women on both attainment and intergenerational persistence can be explained by the fact that girls in a conservative social setting such as that of Jordan are more constrained geographically and are often unable to go to school in a jurisdiction different from their own.

We find that whereas the supply of secondary schooling increases school attainment for male children of uneducated parents, with the effect stemming from both boys' and mixed 
secondary schools, it had no statistically significant effect for females. Moreover, the supply of secondary schools has no differential effect across parental education levels for either males or females (for the latter, the effect in the full sample is positive but it goes away when we restrict the sample to females with at least basic education). We interpret this result as indicating that, in the absence of public secondary schools, educated parents had few outside options given the relative absence of private secondary schools outside the capital Amman. Thus, both educated and uneducated parents were equally constrained by the local supply of public schools.

This research therefore demonstrates that a more progressive governmental policy to construct more public basic schools and to equalize the supply of basic schools across jurisdictions does in fact contribute to improved equality of opportunity in education. It remains to be seen in future research whether it is better in a socially conservative setting such as Jordan to establish single-sex schools or mixed schools if the objective is to improve the educational attainment of girls. 


\section{References}

Abu-Lughod, Ibrahim. "Educating a Community in Exile: The Palestinian Experience.” Journal of Palestine Studies 2 (1973), no. 3: 94-111.

Assaad, Ragui. "Making Sense of Arab Labor Markets: The Enduring Legacy of Dualism.” IZA Journal of Labor \& Development, 2014.

Ayal, Eliezer B. and Barry R. Chiswisk. "The Economics of the Diaspora Revisited." Economic Development and Cultural Change 31 (1983), no. 4: 861-875.

Badran, Nabil A. "The Means of Survival: Education and the Palestinian Community, 19481967.” Journal of Palestine Studies 9 (1980), no. 4: 44-74.

Barro, Robert J., and Jong Wha Lee. "A New Data Set of Educational Attainment in the World, 1950-2010.” Journal of Development Economics 104 (2013): 184-198.

Becker, Gary S., and Nigel Tomes. "An Equilibrium Theory of the Distribution of Income and Intergenerational Mobility.” Journal of Political Economy 87 (1979), no. 6: 1153-1189.

Behrman, J. R., A. D. Foster, M. R. Rosenzweig, and P. Vashishtha. "Women's Schooling, Home Teaching, and Economic Growth.” Journal of Political Economy 107 (1999), no. 4: 682714.

Behrman, J., and B. Wolfe. "Investing in Schooling in Two Generations in Pre-Revolutionary Nicaragua: The Roles of Family Background and School Supply.” Journal of Development Economics 27 (1987), no. 1: 395-419.

Binzel, Christine and J. P. Carvalho. "Education, Social Mobility, and Religious Movements" A Theory of the Islamic Revival in Egypt.” IZA Discussion Paper No. 7259, 2013.

Campante, Filipe R., and Davin Chor. "Why Was the Arab World Poised for Revolution? Schooling, Economic Opportunities, and the Arab Spring." Journal of Economic Perspectives 26 (2012a), no. 2: 167-187.

. "Schooling, Political Participation, and the Economy." Review of Economics and Statistics 94 (2012), no. 4: 841-859.

. "The People Want the Fall of the Regime: Schooling, Political Protest, and the Economy.” Journal of Comparative Economics 42 (2014), no. 3: 495-517.

Card, D., and A. Krueger. "Does School Quality Matter? Returns to Education and the Characteristics of Public Schools in the United States.” Journal of Political Economy 100 (1992), no. 1: 1-39.

Checchi, Daniele, Carlo V. Fiorio, and Marco Leonardi. "Intergenerational Persistence of Educational Attainment in Italy." Economics Letters 118 (2013), no. 1: 229-232.

Checchi, Daniele, and Luca Flabbi. "Intergenerational Mobility and Schooling Decisions in Germany and Italy: The Impact of Secondary School Tracks.” Rivista di Politica Economica 3 (2013), no.7-9, 7-60.

Checchi, Daniele, A. Ichino, and A. Rustichini. "More Equal But Less Mobile? Education Financing and Intergenerational Mobility in Italy and in the US." Journal of Public Economics 74 (1999), no. 3: 351-93. 
Dahan, M., and A. Gaviria. "Sibling Correlations and Intergenerational Mobility in Latin America.” Economic Development and Cultural Change 49 (2001), no. 3: 537-54.

Daouli, J., M. Demoussis, and N. Giannakopoulos. "Mothers, Fathers, and Daughters: Intergenerational Transmission of Education in Greece." Economics of Education Review 29 (2010), no.1: 83-93.

Davies, J. B., J. Zhang, and J. Zeng. "Intergenerational Mobility under Private vs. Public Education.” Scandinavian Journal of Economics 107 (2005), no. 3: 399-417.

Duflo, E. "Schooling and Labor Market Consequences of School Construction in Indonesia: Evidence from an Unusual Policy Experiment.” American Economic Review 91 (2001), no. 4: 795-813.

Frisch, Hillel. "Fuzzy Nationalism: The Case of Jordan.” Nationalism and Ethnic Politics 8 (2002), no. 4: 86-103.

Gellner, E. Nations and Nationalism. Ithaca, NY: Cornell University, 1983.

Goldstone, Jack A. “Understanding the Revolutions of 2011.” Foreign Affairs 90 (2011), no. 3: 8-16.

Hashemite Kingdom of Jordan. Census of Schools 2010. Amman, Jordan: Ministry of Education, 2010.

JLMPS 2010. Jordan Labor Market Panel Survey of 2010. Cairo, Egypt: Economic Research Forum, 2010. Public use microdata available through www.erfdataportal.com. [Accessed June 22, 2013].

Lucas, Russell. "Side Effects of Regime Building in Jordan: The State and the Nation.” Civil Wars 10 (2008), no. 3: 281-293.

Meghir, Costas, and Mårten Palme. "Educational Reform, Ability, and Family Background.” American Economic Review 95 (2005), no. 1: 414-424.

Pritchett, Lant. “Where Has All the Education Gone?” World Bank Economic Review 15 (2001), no. 3: 367-391.

Saleh, Mohamed. "Public Mass Modern Education, Religion, and Human Capital in TwentiethCentury Egypt.” Forthcoming in Journal of Economic History, 2016.

Salehi-Isfahani, D. "The Gender Gap in Education in Iran: Evidence for the Role of Household Characteristics." In Labor and Human Capital in the Middle East: Studies of Markets and Household Behavior, D. Salehi-Isfahani (ed.), Reading, U.K.: Ithaca Press, 2001.

Sanborn, Howard, and Clayton L. Thyne. "Learning Democracy: Education and the Fall of Authoritarian Regimes.” British Journal of Political Science 44 (2014), no. 4: 773-797.

Schütz, G., H. W. Ursprung, and L. Wößmann. "Education Policy and Equality of Opportunity.” KYKLOS 61 (2008), no. 2: 279-308.

Solon, Gary. “A Model of Intergenerational Mobility Variation over Time and Place." In Generational Income Mobility in North America and Europe, Miles Corak (ed.), Cambridge: Cambridge University Press, 2004: 38-47. 


\section{FIGURE I}

\section{Average Years of Schooling by Sex and Year of Birth}

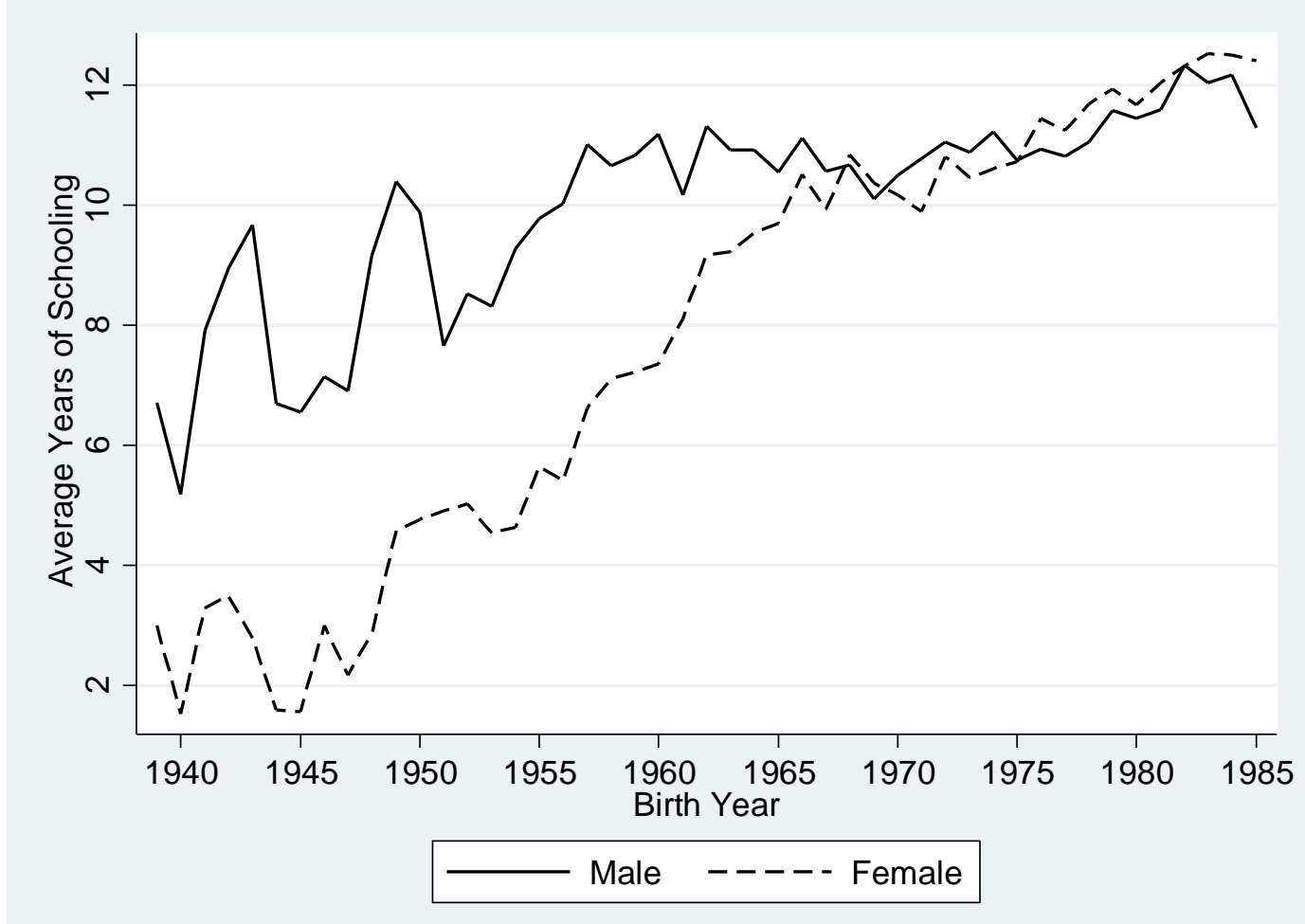

Source: The 2010 Jordan Labor Market Panel Survey matched to the 2010 Jordan school census. The sample is restricted to individuals who are aged 25 to 70 years in 2010, are born in Jordan, and with non-missing values on age, sub-district of birth, years of schooling, father's schooling, mother's schooling, and the local supply of schools in the sub-district of birth. 
FIGURE II

\section{Average Number of Public Schools (Per 1,000 Individuals) by Birth Year}
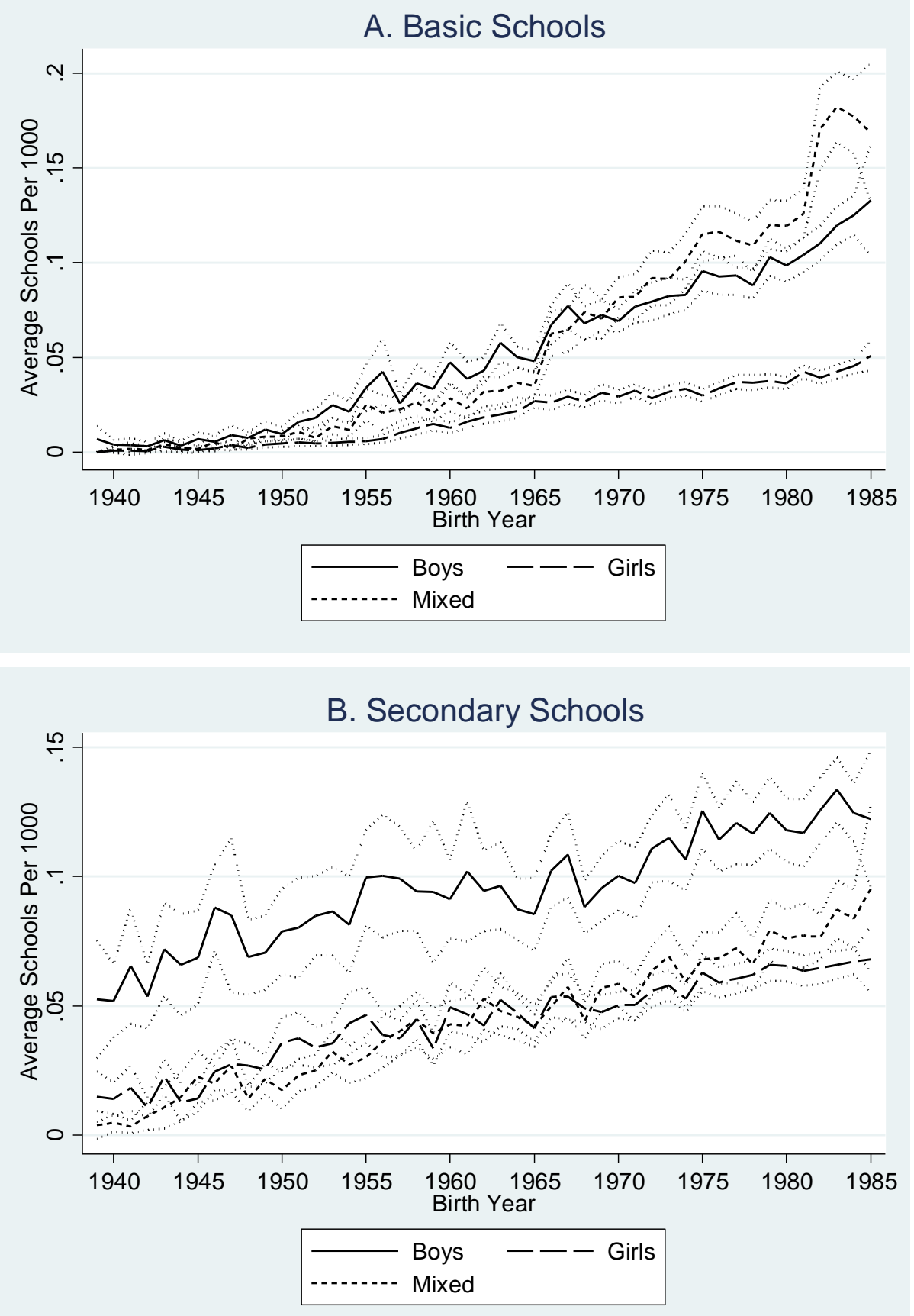

Source: The 2010 Jordan Labor Market Panel Survey matched to the 2010 Jordan school census. The sample is restricted to individuals who are aged 25 to 70 years in 2010, are born in Jordan, and with non-missing values on age, sub-district of birth, years of schooling, father's schooling, mother's schooling, and the local supply of schools in the sub-district of birth.

Notes: Averages are computed across all individuals in the sample, where the upper and lower bounds of the confidence intervals are shown. Basic schools are the asasi schools, while secondary schools include secondary (acadimi) and vocational (mihani) schools plus schools with both secondary and vocational sections (acadimi + 
mihani). Public schools lie under the jurisdiction of Ministry of Education, Ministry of Higher Education, Ministry of Defense, Ministry of Social Development, Ministry of Religious Endowments (awqaf), and UNRWA.

\section{FIGURE III \\ Estimated Coefficient of Intergenerational Transmission of Educational Attainment}

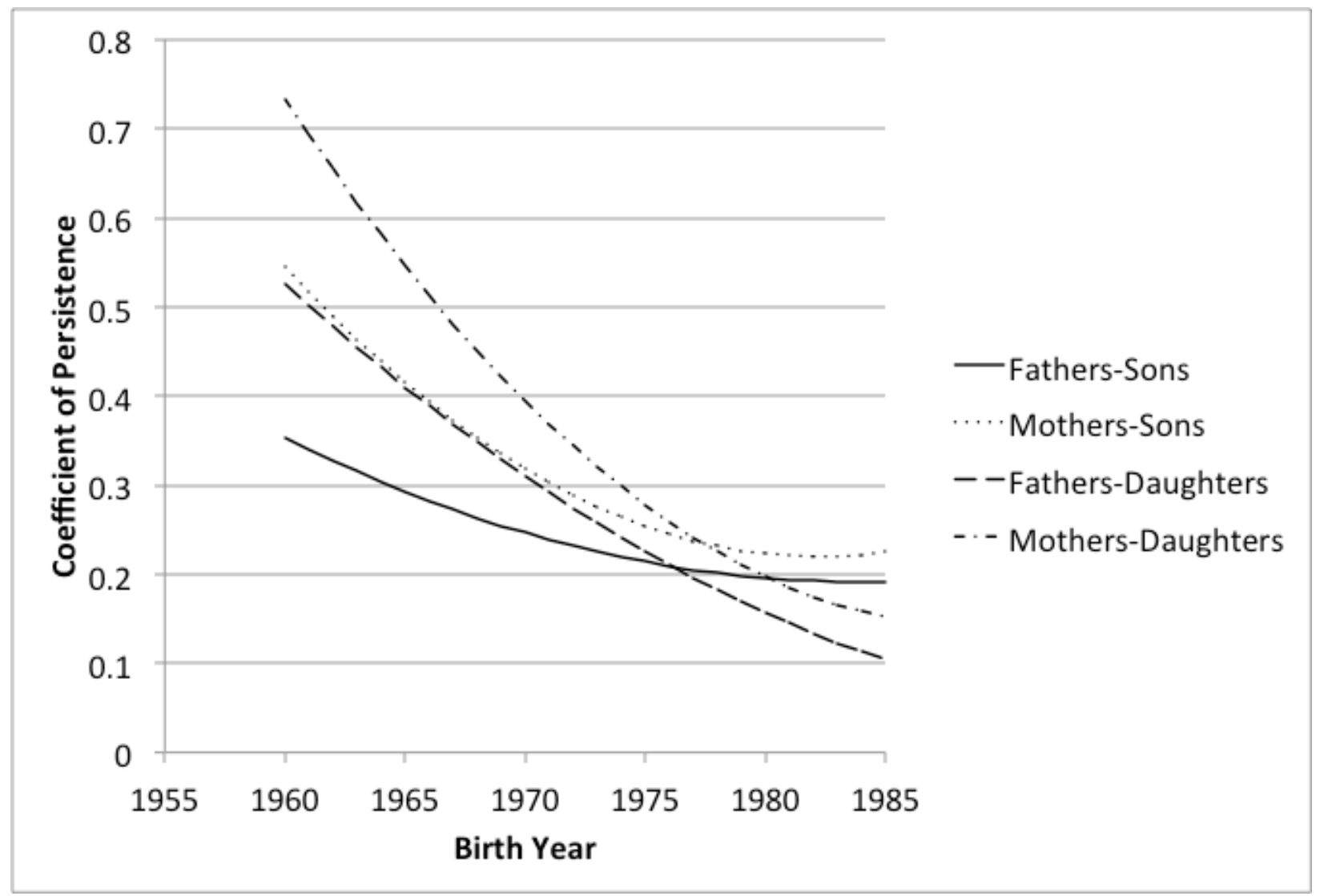

Source: The 2010 Jordan Labor Market Panel Survey matched to the 2010 Jordan school census. The sample is restricted to individuals who are aged 25 to 70 years in 2010, are born in Jordan, and with non-missing values on age, sub-district of birth, years of schooling, father's schooling, mother's schooling, and the local supply of schools in the sub-district of birth.

Notes: Graph is based on estimating a regression of child's schooling on parent's schooling, age deviation from the mean, square of age deviation (divided by 100), interaction of parent's schooling with age, and interaction of parent's schooling with age deviation squared (divided by 100). 


\section{TABLE I}

\section{Correlates of the Growth of the Local Supply of Public Schools}

\begin{tabular}{|c|c|c|c|c|c|c|c|c|}
\hline & \multicolumn{4}{|c|}{$\begin{array}{l}\text { Dependent variable: Average Annual Growth of } \\
\text { Basic Public Schools in 1946-1991 }\end{array}$} & \multicolumn{4}{|c|}{$\begin{array}{l}\text { Dependent variable: Average Annual Growth of } \\
\text { Secondary Public Schools in 1955-2000 }\end{array}$} \\
\hline & (1) & (2) & (3) & (4) & (5) & (6) & (7) & (8) \\
\hline & Girls' & Boys' & Mixed & All & Girls' & Boys' & Mixed & All \\
\hline & Schools & Schools & Schools & Schools & Schools & Schools & Schools & Schools \\
\hline \% Primary and below & 0.175 & $-0.155^{*}$ & 0.155 & -0.005 & 0.030 & -0.042 & -0.009 & $-0.091^{* * *}$ \\
\hline$(60+$ in 2004$)$ & $(0.160)$ & $(0.087)$ & $(0.148)$ & $(0.084)$ & $(0.053)$ & $(0.032)$ & $(0.053)$ & $(0.034)$ \\
\hline$\%$ Secondary and below & -0.234 & -0.003 & -0.042 & 0.013 & -0.189 & -0.108 & -0.116 & -0.109 \\
\hline university (60+ in 2004) & $(0.387)$ & $(0.210)$ & $(0.249)$ & $(0.164)$ & $(0.134)$ & $(0.072)$ & $(0.158)$ & $(0.101)$ \\
\hline$\%$ University and above (60+ & $0.729^{*}$ & $-0.275^{*}$ & 0.021 & -0.027 & -0.028 & -0.044 & 0.130 & -0.060 \\
\hline in 2004) & $(0.363)$ & $(0.143)$ & $(0.287)$ & $(0.163)$ & $(0.130)$ & $(0.068)$ & $(0.128)$ & $(0.095)$ \\
\hline$\%$ White-Collar (50+ in & $-0.196^{* *}$ & 0.049 & -0.116 & -0.034 & 0.003 & -0.024 & 0.006 & -0.010 \\
\hline 2004) & $(0.080)$ & $(0.062)$ & $(0.093)$ & $(0.046)$ & $(0.035)$ & $(0.015)$ & $(0.036)$ & $(0.021)$ \\
\hline \% Born outside Jordan (60+ & 0.029 & -0.004 & -0.074 & -0.045 & 0.048 & -0.002 & 0.016 & 0.015 \\
\hline in 2004) & $(0.037)$ & $(0.040)$ & $(0.046)$ & $(0.032)$ & $(0.031)$ & $(0.013)$ & $(0.022)$ & $(0.014)$ \\
\hline Initial number of schools & -0.001 & 0.006 & $-0.049^{* * *}$ & $-0.014^{* * *}$ & -0.005 & $-0.004^{* * * *}$ & $-0.010^{* *}$ & $-0.004^{* * *}$ \\
\hline & $(0.011)$ & $(0.012)$ & $(0.015)$ & $(0.005)$ & $(0.007)$ & $(0.001)$ & $(0.004)$ & $(0.001)$ \\
\hline Log (total population in & $0.020^{* * *}$ & $0.025^{* * *}$ & $0.018^{*}$ & $0.019^{* * *}$ & $0.014^{* * *}$ & $0.013^{* * *}$ & $0.015^{* *}$ & $0.010^{* * *}$ \\
\hline 2004) & $(0.007)$ & $(0.007)$ & $(0.010)$ & $(0.006)$ & $(0.005)$ & $(0.003)$ & $(0.006)$ & $(0.003)$ \\
\hline Governorate fixed effects? & Yes & Yes & Yes & Yes & Yes & Yes & Yes & Yes \\
\hline Observations (sub-districts) & 39 & 75 & 87 & 88 & 76 & 89 & 80 & 89 \\
\hline
\end{tabular}

Source: The 2010 Jordan school census matched at the sub-district level with data on educational and occupational attainment and place of birth from the 2004 population census.

Notes: ${ }^{*} \mathrm{p}<0.10,{ }^{* *} \mathrm{p}<0.05,{ }^{* * *} \mathrm{p}<0.01$. Heteroskedasticity-robust standard errors are in parentheses. The number of observations varies from one regression to the other because some sub-districts may not have a certain type of school. 
TABLE II

Summary Statistics - Males and Females (Age 25-70)

\begin{tabular}{lcc}
\hline & Males & Females \\
\hline Years of schooling & 10.79 & 9.83 \\
& $(3.97)$ & $(4.95)$ \\
Father's schooling & 3.10 & 3.39 \\
& $(4.19)$ & $(4.40)$ \\
Mother's schooling & 1.49 & 1.59 \\
& $(3.13)$ & $(3.28)$ \\
Boys' basic schools per 1000 & 0.08 & 0.07 \\
& $(0.08)$ & $(0.08)$ \\
Girls' basic schools per 1000 & 0.03 & 0.03 \\
& $(0.03)$ & $(0.03)$ \\
Mixed basic schools per 1000 & 0.09 & 0.09 \\
& $(0.13)$ & $(0.12)$ \\
Total basic schools available to males per 1000 & 0.16 & 0.16 \\
individuals = Boys' schools + Mixed schools & $(0.19)$ & $(0.18)$ \\
Total basic schools available to females per 1000 & 0.11 & 0.12 \\
individuals = Girls' schools + Mixed Schools & $(0.13)$ & $(0.13)$ \\
Boys' secondary schools per 1000 & 0.11 & 0.11 \\
& $(0.11)$ & $(0.11)$ \\
Girls' secondary schools per 1000 & 0.05 & 0.05 \\
& $(0.05)$ & $(0.05)$ \\
Mixed secondary schools per 1000 & 0.06 & 0.06 \\
& $(0.09)$ & $(0.09)$ \\
Total secondary schools available to males per 1000 & 0.17 & 0.16 \\
individuals = Boys' schools + Mixed schools & $(0.19)$ & $(0.19)$ \\
Total secondary schools available to females per & 0.11 & 0.11 \\
1000 individuals = Girls' schools + Mixed Schools & $(0.12)$ & $(0.12)$ \\
\hline Observations & 4139 & 4131 \\
\hline
\end{tabular}

Source: The 2010 Jordan Labor Market Panel Survey matched to the 2010 Jordan school census. The sample is restricted to individuals who are aged 25 to 70 years in 2010, are born in Jordan, and with non-missing values on age, sub-district of birth, years of schooling, father's schooling, mother's schooling, and the local supply of schools in the sub-district of birth.

Notes: Means are reported and standard deviations are in parentheses. 


\section{TABLE III}

\section{Intergenerational Mobility of Education: Basic Regressions}

\begin{tabular}{|c|c|c|c|c|c|c|c|c|}
\hline & \multicolumn{2}{|c|}{ Males-Fathers } & \multicolumn{2}{|c|}{ Males-Mothers } & \multicolumn{2}{|c|}{ Females-Fathers } & \multicolumn{2}{|c|}{ Females-Mothers } \\
\hline & (1) & (2) & (3) & (4) & (5) & (6) & (7) & (8) \\
\hline & Model 1 & Model 2 & Model 1 & Model 2 & Model 1 & Model 2 & Model 1 & Model 2 \\
\hline Parent's schooling & $0.232^{* * *}$ & $0.241^{* * * *}$ & $0.263^{* * *}$ & $0.301^{* * *}$ & $0.243^{* * *}$ & $0.297^{* * *}$ & $0.274^{* * *}$ & $0.368^{* * *}$ \\
\hline & $(0.015)$ & $(0.017)$ & $(0.024)$ & $(0.027)$ & $(0.012)$ & $(0.020)$ & $(0.021)$ & $(0.029)$ \\
\hline Age deviation & $\begin{array}{c}-0.044^{* * *} \\
(0.011)\end{array}$ & $\begin{array}{c}-0.062^{* * *} \\
(0.013)\end{array}$ & $\begin{array}{c}-0.046^{* * *} \\
(0.012)\end{array}$ & $\begin{array}{c}-0.057^{* * * *} \\
(0.013)\end{array}$ & $\begin{array}{c}-0.174^{* * *} \\
(0.020)\end{array}$ & $\begin{array}{c}-0.228^{* * * *} \\
(0.020)\end{array}$ & $\begin{array}{c}-0.180^{* * * *} \\
(0.022)\end{array}$ & $\begin{array}{c}-0.205^{* * *} \\
(0.021)\end{array}$ \\
\hline Age deviation squared/100 & $\begin{array}{c}-0.225^{* * * *} \\
(0.054)\end{array}$ & $\begin{array}{c}-0.208^{* * *} \\
(0.061)\end{array}$ & $\begin{array}{l}-0.246^{* * *} \\
(0.053)\end{array}$ & $\begin{array}{l}-0.225^{* * *} \\
(0.057)\end{array}$ & $\begin{array}{c}-0.422^{* * *} \\
(0.060)\end{array}$ & $\begin{array}{l}-0.305^{* * *} \\
(0.074)\end{array}$ & $\begin{array}{c}-0.425^{* * *} \\
(0.063)\end{array}$ & $\begin{array}{c}-0.360^{* * *} \\
(0.074)\end{array}$ \\
\hline $\begin{array}{l}\text { Parent's schooling * age } \\
\text { deviation }\end{array}$ & & $\begin{array}{l}0.008^{* * *} \\
(0.002)\end{array}$ & & $\begin{array}{l}0.015^{* * *} \\
(0.003)\end{array}$ & & $\begin{array}{l}0.018^{* * *} \\
(0.002)\end{array}$ & & $\begin{array}{l}0.025^{* * *} \\
(0.005)\end{array}$ \\
\hline Parent's schooling * age & & $0.027^{* *}$ & & $0.070^{* * * *}$ & & $0.030^{*}$ & & $0.077^{*}$ \\
\hline deviation sq./100 & & $(0.012)$ & & $(0.025)$ & & $(0.016)$ & & $(0.039)$ \\
\hline Sub-district of birth FE? & Yes & Yes & Yes & Yes & Yes & Yes & Yes & Yes \\
\hline Observations & 4139 & 4139 & 4139 & 4139 & 4131 & 4131 & 4131 & 4131 \\
\hline Adjusted $R^{2}$ & 0.173 & 0.179 & 0.158 & 0.163 & 0.419 & 0.440 & 0.407 & 0.422 \\
\hline
\end{tabular}

Source: The 2010 Jordan Labor Market Panel Survey matched to the 2010 Jordan school census. The sample is restricted to individuals who are aged 25 to 70 years in 2010, are born in Jordan, and with nonmissing values on age, sub-district of birth, years of schooling, father's schooling, mother's schooling, and the local supply of schools in the sub-district of birth.

Notes: ${ }^{*} \mathrm{p}<0.10,{ }^{* *} \mathrm{p}<0.05$, and ${ }^{* * *} \mathrm{p}<0.01$. Standard errors clustered at the sub-district of birth level are in parentheses. 
TABLE IV

\section{Intergenerational Educational Mobility and Local Supply of Public Schools - Full Sample - Equation (2)}

\section{A. Male Sample}

\begin{tabular}{|c|c|c|c|c|c|c|c|c|}
\hline & \multicolumn{4}{|c|}{ Males-Fathers } & \multicolumn{4}{|c|}{ Males-Mothers } \\
\hline & (1) & (2) & (3) & (4) & (5) & (6) & (7) & (8) \\
\hline Parent's schooling & $\begin{array}{l}0.284^{* * *} \\
(0.017)\end{array}$ & $\begin{array}{l}0.300^{* * *} \\
(0.019)\end{array}$ & $\begin{array}{l}0.280^{* * *} \\
(0.018)\end{array}$ & $\begin{array}{l}0.289^{* * *} \\
(0.020)\end{array}$ & $\begin{array}{l}0.310^{* * *} \\
(0.038)\end{array}$ & $\begin{array}{l}0.318^{* * *} \\
(0.042)\end{array}$ & $\begin{array}{l}0.317^{* * *} \\
(0.040)\end{array}$ & $\begin{array}{l}0.309^{* * *} \\
(0.042)\end{array}$ \\
\hline Total basic schools per 1000 & $\begin{array}{l}3.181^{* * * *} \\
(0.865)\end{array}$ & & $\begin{array}{l}1.294 \\
(0.801)\end{array}$ & & $\begin{array}{l}2.989^{* * *} \\
(0.842)\end{array}$ & & $\begin{array}{l}1.186 \\
(0.739)\end{array}$ & \\
\hline Parent's schooling * total & $-0.275^{* *}$ & & $-0.242^{*}$ & & $-0.320^{*}$ & & -0.306 & \\
\hline basic schools & $(0.120)$ & & $(0.127)$ & & $(0.187)$ & & $(0.197)$ & \\
\hline Total secondary schools per & $4.949^{* * * *}$ & & $4.447^{* * * *}$ & & $4.910^{\text {*a* }}$ & & $4.462^{* * * *}$ & \\
\hline 1000 & (1.108) & & $(1.250)$ & & (1.133) & & $(1.282)$ & \\
\hline $\begin{array}{l}\text { Parent's schooling * total } \\
\text { secondary schools }\end{array}$ & $\begin{array}{l}-0.002 \\
(0.140)\end{array}$ & & $\begin{array}{l}-0.008 \\
(0.146)\end{array}$ & & $\begin{array}{c}0.096 \\
(0.185)\end{array}$ & & $\begin{array}{c}0.039 \\
(0.189)\end{array}$ & \\
\hline Boys' basic schools per 1000 & & $\begin{array}{c}2.422 \\
(2.036)\end{array}$ & & $\begin{array}{l}-0.336 \\
(2.218)\end{array}$ & & $\begin{array}{c}1.790 \\
(1.959)\end{array}$ & & $\begin{array}{l}-0.952 \\
(2.129)\end{array}$ \\
\hline $\begin{array}{l}\text { Parent's schooling * boys' } \\
\text { basic schools }\end{array}$ & & $\begin{array}{l}-0.445^{*} \\
(0.230)\end{array}$ & & $\begin{array}{l}-0.302 \\
(0.271)\end{array}$ & & $\begin{array}{l}-0.279 \\
(0.358)\end{array}$ & & $\begin{array}{l}-0.113 \\
(0.384)\end{array}$ \\
\hline Mixed basic schools per 1000 & & $\begin{array}{l}3.430^{* * *} \\
(1.135)\end{array}$ & & $\begin{array}{c}1.789 \\
(1.129)\end{array}$ & & $\begin{array}{l}3.428^{* * *} \\
(1.125)\end{array}$ & & $\begin{array}{l}1.867^{*} \\
(1.078)\end{array}$ \\
\hline $\begin{array}{l}\text { Parent's schooling * mixed } \\
\text { basic schools }\end{array}$ & & $\begin{array}{l}-0.210 \\
(0.173)\end{array}$ & & $\begin{array}{l}-0.221 \\
(0.180)\end{array}$ & & $\begin{array}{l}-0.324 \\
(0.217)\end{array}$ & & $\begin{array}{l}-0.386 \\
(0.243)\end{array}$ \\
\hline Boys' secondary schools per & & $5.004^{*}$ & & 3.627 & & $4.777^{*}$ & & 3.478 \\
\hline 1000 & & $(2.546)$ & & $(2.608)$ & & $(2.506)$ & & $(2.505)$ \\
\hline $\begin{array}{l}\text { Parent's schooling * boys' } \\
\text { secondary schools }\end{array}$ & & $\begin{array}{l}-0.423 \\
(0.457)\end{array}$ & & $\begin{array}{l}-0.261 \\
(0.514)\end{array}$ & & $\begin{array}{l}-0.224 \\
(0.662)\end{array}$ & & $\begin{array}{c}0.055 \\
(0.719)\end{array}$ \\
\hline Mixed secondary schools per & & $4.626^{*}$ & & $5.206^{*}$ & & $4.989^{* * *}$ & & $5.546^{*}$ \\
\hline 1000 & & (2.414) & & (2.759) & & $(2.398)$ & & $(2.790)$ \\
\hline $\begin{array}{l}\text { Parent's schooling * mixed } \\
\text { secondary schools }\end{array}$ & & $\begin{array}{c}0.561 \\
(0.486)\end{array}$ & & $\begin{array}{c}0.325 \\
(0.546)\end{array}$ & & $\begin{array}{c}0.414 \\
(0.570)\end{array}$ & & $\begin{array}{l}-0.011 \\
(0.635)\end{array}$ \\
\hline Year of birth FE? & Yes & Yes & Yes & Yes & Yes & Yes & Yes & Yes \\
\hline Sub-district of birth FE? & Yes & Yes & Yes & Yes & Yes & Yes & Yes & Yes \\
\hline $\begin{array}{l}\text { Governorate of birth FE * } \\
\text { Year of birth FE? }\end{array}$ & No & No & Yes & Yes & No & No & Yes & Yes \\
\hline Observations & 4139 & 4139 & 4139 & 4139 & 4139 & 4139 & 4139 & 4139 \\
\hline Adjusted $R^{2}$ & 0.194 & 0.194 & 0.209 & 0.208 & 0.176 & 0.175 & 0.191 & 0.190 \\
\hline
\end{tabular}




\section{B. Female Sample}

\begin{tabular}{|c|c|c|c|c|c|c|c|c|}
\hline & \multicolumn{4}{|c|}{ Females-Fathers } & \multicolumn{4}{|c|}{ Females-Mothers } \\
\hline & (1) & (2) & (3) & (4) & (5) & (6) & (7) & (8) \\
\hline Parent's schooling & $\begin{array}{l}0.286^{* * *} \\
(0.024)\end{array}$ & $\begin{array}{c}0.377^{* * *} \\
(0.041)\end{array}$ & $\begin{array}{l}0.274^{* * *} \\
(0.024)\end{array}$ & $\begin{array}{l}0.342^{* * *} \\
(0.037)\end{array}$ & $\begin{array}{c}0.348^{* * *} \\
(0.036)\end{array}$ & $\begin{array}{l}0.398^{* * *} \\
(0.061)\end{array}$ & $\begin{array}{l}0.347^{* * *} \\
(0.039)\end{array}$ & $\begin{array}{l}0.353^{* * *} \\
(0.057)\end{array}$ \\
\hline Total basic schools per 1000 & $\begin{array}{l}9.448^{* * *} \\
(1.891)\end{array}$ & & $\begin{array}{l}5.480^{* * *} \\
(1.340)\end{array}$ & & $\begin{array}{l}8.230^{* * *} \\
(1.841)\end{array}$ & & $\begin{array}{l}4.223^{* * *} \\
(1.390)\end{array}$ & \\
\hline Parent's schooling * total & $-0.973^{* * * *}$ & & $-0.798^{* * * *}$ & & $-0.890^{* * *}$ & & $-0.720^{* *}$ & \\
\hline basic schools & (0.219) & & $(0.195)$ & & $(0.268)$ & & $(0.288)$ & \\
\hline Total secondary schools per & -0.648 & & -0.584 & & 0.632 & & 0.743 & \\
\hline 1000 & (2.367) & & $(2.231)$ & & $(2.501)$ & & $(2.287)$ & \\
\hline $\begin{array}{l}\text { Parent's schooling * total } \\
\text { secondary schools }\end{array}$ & $\begin{array}{l}0.950^{* * *} \\
(0.195)\end{array}$ & & $\begin{array}{c}0.732^{* * *} \\
(0.187)\end{array}$ & & $\begin{array}{c}0.673^{* * *} \\
(0.230)\end{array}$ & & $\begin{array}{c}0.455 \\
(0.302)\end{array}$ & \\
\hline Girls' basic schools per 1000 & & $\begin{array}{l}-9.922 \\
(9.624)\end{array}$ & & $\begin{array}{r}-10.424 \\
(9.239)\end{array}$ & & $\begin{array}{l}-18.714^{*} \\
(10.403)\end{array}$ & & $\begin{array}{r}-17.320^{*} \\
(9.811)\end{array}$ \\
\hline $\begin{array}{l}\text { Parent's schooling * girls' } \\
\text { basic schools }\end{array}$ & & $\begin{array}{c}-2.255^{* * *} \\
(0.399)\end{array}$ & & $\begin{array}{c}-1.662^{* * * *} \\
(0.402)\end{array}$ & & $\begin{array}{l}-0.789 \\
(0.719)\end{array}$ & & $\begin{array}{l}-0.008 \\
(0.726)\end{array}$ \\
\hline Mixed basic schools per 1000 & & $\begin{array}{l}8.497^{* * *} \\
(1.581)\end{array}$ & & $\begin{array}{l}5.524^{* * *} \\
(1.370)\end{array}$ & & $\begin{array}{l}7.913^{* * *} \\
(1.631)\end{array}$ & & $\begin{array}{l}4.771^{* * *} \\
(1.458)\end{array}$ \\
\hline $\begin{array}{l}\text { Parent's schooling * mixed } \\
\text { basic schools }\end{array}$ & & $\begin{array}{c}-0.772^{* * *} \\
(0.207)\end{array}$ & & $\begin{array}{c}-0.668^{* * *} \\
(0.194)\end{array}$ & & $\begin{array}{c}-0.846^{* * *} \\
(0.262)\end{array}$ & & $\begin{array}{c}-0.741^{* * *} \\
(0.270)\end{array}$ \\
\hline Girls' secondary schools per & & $-6.241^{*}$ & & -5.721 & & $-6.865^{*}$ & & -6.193 \\
\hline 1000 & & $(3.512)$ & & (4.195) & & $(3.486)$ & & $(4.413)$ \\
\hline Parent's schooling * girls' & & -0.478 & & -0.487 & & $-1.161^{*}$ & & -0.947 \\
\hline secondary schools & & $(0.437)$ & & $(0.463)$ & & $(0.648)$ & & $(0.721)$ \\
\hline Mixed secondary schools per & & 0.852 & & 0.781 & & 2.264 & & 2.229 \\
\hline 1000 & & $(2.960)$ & & (3.142) & & (3.041) & & (3.174) \\
\hline $\begin{array}{l}\text { Parent's schooling * mixed } \\
\text { secondary schools }\end{array}$ & & $\begin{array}{l}1.156^{* * *} \\
(0.259)\end{array}$ & & $\begin{array}{l}1.032^{* * *} \\
(0.257)\end{array}$ & & $\begin{array}{l}1.539^{* * *} \\
(0.432)\end{array}$ & & $\begin{array}{l}1.354^{* * *} \\
(0.428)\end{array}$ \\
\hline Year of birth FE? & Yes & Yes & Yes & Yes & Yes & Yes & Yes & Yes \\
\hline Sub-district of birth FE? & Yes & Yes & Yes & Yes & Yes & Yes & Yes & Yes \\
\hline $\begin{array}{l}\text { Governorate of birth FE * } \\
\text { Year of birth FE? }\end{array}$ & No & No & Yes & Yes & No & No & Yes & Yes \\
\hline Observations & 4131 & 4131 & 4131 & 4131 & 4131 & 4131 & 4131 & 4131 \\
\hline Adjusted $R^{2}$ & 0.432 & 0.439 & 0.450 & 0.453 & 0.417 & 0.424 & 0.439 & 0.442 \\
\hline
\end{tabular}

Source: The 2010 Jordan Labor Market Panel Survey matched to the 2010 Jordan school census. The sample is restricted to individuals who are aged 25 to 70 years in 2010, are born in Jordan, and with nonmissing values on age, sub-district of birth, years of schooling, father's schooling, mother's schooling, and the local supply of schools in the sub-district of birth.

Notes: ${ }^{*} \mathrm{p}<0.10,{ }^{* *} \mathrm{p}<0.05$, and ${ }^{* * *} \mathrm{p}<0.01$. Standard errors clustered at the sub-district of birth level are in parentheses. 


\section{TABLE V}

\section{Intergenerational Educational Mobility and Local Supply of Public Schools - Sample with at Least Basic Schooling - Equation (2)}

\section{A. Male Sample}

\begin{tabular}{|c|c|c|c|c|c|c|c|c|}
\hline & \multicolumn{4}{|c|}{ Fathers } & \multicolumn{4}{|c|}{ Mothers } \\
\hline & (1) & (2) & (3) & (4) & (5) & (6) & (7) & (8) \\
\hline Parent's schooling & $\begin{array}{l}0.121^{* * *} \\
(0.013)\end{array}$ & $\begin{array}{l}0.129^{* * *} \\
(0.016)\end{array}$ & $\begin{array}{l}0.116^{* * *} \\
(0.015)\end{array}$ & $\begin{array}{l}0.118^{* * *} \\
(0.019)\end{array}$ & $\begin{array}{l}0.160^{* * *} \\
(0.035)\end{array}$ & $\begin{array}{l}0.155^{* * *} \\
(0.040)\end{array}$ & $\begin{array}{l}0.156^{* * *} \\
(0.039)\end{array}$ & $\begin{array}{l}0.144^{* * *} \\
(0.042)\end{array}$ \\
\hline Total basic schools per 1000 & $\begin{array}{l}1.098^{* *} \\
(0.514)\end{array}$ & & $\begin{array}{c}0.670 \\
(0.516)\end{array}$ & & $\begin{array}{l}1.321^{* *} \\
(0.568)\end{array}$ & & $\begin{array}{l}0.843^{*} \\
(0.467)\end{array}$ & \\
\hline Parent's schooling * total & 0.018 & & 0.013 & & -0.042 & & -0.070 & \\
\hline basic schools & $(0.066)$ & & $(0.077)$ & & $(0.128)$ & & $(0.137)$ & \\
\hline Total secondary schools per & 2.247 & & $3.037^{* *}$ & & 2.102 & & 2.646 & \\
\hline 1000 & $(1.481)$ & & $(1.463)$ & & $(1.487)$ & & $(1.592)$ & \\
\hline $\begin{array}{l}\text { Parent's schooling * total } \\
\text { secondary schools }\end{array}$ & $\begin{array}{l}-0.092 \\
(0.091)\end{array}$ & & $\begin{array}{l}-0.069 \\
(0.105)\end{array}$ & & $\begin{array}{c}0.015 \\
(0.148)\end{array}$ & & $\begin{array}{c}0.067 \\
(0.170)\end{array}$ & \\
\hline Boys' basic schools per 1000 & & $\begin{array}{c}0.006 \\
(1.830)\end{array}$ & & $\begin{array}{l}-1.595 \\
(1.945)\end{array}$ & & $\begin{array}{c}0.284 \\
(1.846)\end{array}$ & & $\begin{array}{l}-1.138 \\
(1.963)\end{array}$ \\
\hline Parent's schooling * boys' & & -0.072 & & 0.029 & & -0.015 & & 0.051 \\
\hline basic schools & & $(0.194)$ & & $(0.237)$ & & $(0.332)$ & & $(0.384)$ \\
\hline Mixed basic schools per 1000 & & $\begin{array}{l}1.329^{*} \\
(0.743)\end{array}$ & & $\begin{array}{l}1.273 \\
(0.769)\end{array}$ & & $\begin{array}{l}1.582^{*} \\
(0.821)\end{array}$ & & $\begin{array}{l}1.400^{*} \\
(0.773)\end{array}$ \\
\hline $\begin{array}{l}\text { Parent's schooling * mixed } \\
\text { basic schools }\end{array}$ & & $\begin{array}{c}0.054 \\
(0.132)\end{array}$ & & 0.002 & & $\begin{array}{c}-0.062 \\
(0.168)\end{array}$ & & $\begin{array}{l}-0.136 \\
(0.186)\end{array}$ \\
\hline Boys' secondary schools per & & 1.692 & & 3.675 & & 1.877 & & 3.593 \\
\hline 1000 & & $(2.622)$ & & $(2.332)$ & & $(2.675)$ & & $(2.529)$ \\
\hline Parent's schooling * boys' & & -0.282 & & -0.183 & & 0.176 & & 0.326 \\
\hline secondary schools & & $(0.189)$ & & $(0.238)$ & & $(0.332)$ & & $(0.370)$ \\
\hline Mixed secondary schools per & & 2.453 & & 3.029 & & 2.524 & & 2.751 \\
\hline 1000 & & $(2.205)$ & & $(2.418)$ & & $(2.182)$ & & $(2.510)$ \\
\hline $\begin{array}{l}\text { Parent's schooling * mixed } \\
\text { secondary schools }\end{array}$ & & $\begin{array}{c}0.151 \\
(0.248)\end{array}$ & & $\begin{array}{c}0.082 \\
(0.314)\end{array}$ & & $\begin{array}{l}-0.159 \\
(0.355)\end{array}$ & & $\begin{array}{l}-0.198 \\
(0.421)\end{array}$ \\
\hline Year of birth FE? & Yes & Yes & Yes & Yes & Yes & Yes & Yes & Yes \\
\hline Sub-district of birth FE? & Yes & Yes & Yes & Yes & Yes & Yes & Yes & Yes \\
\hline $\begin{array}{l}\text { Governorate of birth FE * } \\
\text { Year of birth FE? }\end{array}$ & No & No & Yes & Yes & No & No & Yes & Yes \\
\hline Observations & 2710 & 2710 & 2710 & 2710 & 2710 & 2710 & 2710 & 2710 \\
\hline Adjusted $R^{2}$ & 0.079 & 0.078 & 0.090 & 0.089 & 0.083 & 0.082 & 0.095 & 0.094 \\
\hline
\end{tabular}




\section{B. Female Sample}

\begin{tabular}{|c|c|c|c|c|c|c|c|c|}
\hline & \multicolumn{4}{|c|}{ Fathers } & \multicolumn{4}{|c|}{ Mothers } \\
\hline & (1) & (2) & (3) & (4) & (5) & (6) & (7) & (8) \\
\hline Parent's schooling & $\begin{array}{l}0.100^{* * *} \\
(0.014)\end{array}$ & $\begin{array}{l}0.077^{* * *} \\
(0.021)\end{array}$ & $\begin{array}{l}0.103^{* * *} \\
(0.014)\end{array}$ & $\begin{array}{l}0.081^{* * *} \\
(0.022)\end{array}$ & $\begin{array}{l}0.155^{* * *} \\
(0.019)\end{array}$ & $\begin{array}{l}0.107^{* * *} \\
(0.031)\end{array}$ & $\begin{array}{l}0.155^{* * *} \\
(0.022)\end{array}$ & $\begin{array}{l}0.093^{* *} \\
(0.041)\end{array}$ \\
\hline Total basic schools per 1000 & $\begin{array}{l}1.842^{* * *} \\
(0.878)\end{array}$ & & $\begin{array}{l}1.719 \\
(1.229)\end{array}$ & & $\begin{array}{l}2.170^{* * *} \\
(0.844)\end{array}$ & & $\begin{array}{l}1.982 \\
(1.229)\end{array}$ & \\
\hline $\begin{array}{l}\text { Parent's schooling * total } \\
\text { basic schools }\end{array}$ & $\begin{array}{c}0.005 \\
(0.098)\end{array}$ & & $\begin{array}{c}0.051 \\
(0.109)\end{array}$ & & $\begin{array}{l}-0.082 \\
(0.141)\end{array}$ & & $\begin{array}{l}-0.027 \\
(0.160)\end{array}$ & \\
\hline Total secondary schools per & 0.328 & & 1.051 & & 0.307 & & 0.161 & \\
\hline 1000 & $(2.457)$ & & $(2.956)$ & & (2.489) & & (3.179) & \\
\hline $\begin{array}{l}\text { Parent's schooling * total } \\
\text { secondary schools }\end{array}$ & $\begin{array}{c}0.014 \\
(0.107)\end{array}$ & & $\begin{array}{l}-0.082 \\
(0.108)\end{array}$ & & $\begin{array}{c}0.064 \\
(0.121)\end{array}$ & & $\begin{array}{l}-0.027 \\
(0.155)\end{array}$ & \\
\hline Girls' basic schools per 1000 & & $\begin{array}{l}-5.703 \\
(4.799)\end{array}$ & & $\begin{array}{l}-1.141 \\
(5.763)\end{array}$ & & $\begin{array}{l}-8.379^{*} \\
(4.992)\end{array}$ & & $\begin{array}{l}-3.532 \\
(6.183)\end{array}$ \\
\hline Parent's schooling * girls' & & $0.494^{*}$ & & 0.473 & & $0.988^{* * *}$ & & $1.248^{* * *}$ \\
\hline $\begin{array}{l}\text { basic schools } \\
\text { Mixed basic schools per } 1000\end{array}$ & & $\begin{array}{c}(0.267) \\
1.601^{*} \\
(0.883)\end{array}$ & & $\begin{array}{c}(0.305) \\
1.509 \\
(1.329)\end{array}$ & & $\begin{array}{l}(0.377) \\
1.737^{* *} \\
(0.827)\end{array}$ & & $\begin{array}{c}(0.462) \\
1.638 \\
(1271)\end{array}$ \\
\hline Parent's schooling * mixed & & -0.032 & & 0.009 & & -0.128 & & -0.120 \\
\hline $\begin{array}{l}\text { basic schools } \\
\text { Girls' secondary schools per }\end{array}$ & & $\begin{array}{c}(0.098) \\
-13.450^{*}\end{array}$ & & $\begin{array}{l}(0.109) \\
-15.557^{*}\end{array}$ & & $\begin{array}{l}(0.143) \\
-14.502^{* *}\end{array}$ & & $\begin{array}{l}(0.152) \\
-16.218\end{array}$ \\
\hline 1000 & & $(6.967)$ & & $(8.377)$ & & (7.194) & & $(9.013)$ \\
\hline Parent's schooling * girls' & & 0.114 & & 0.063 & & 0.029 & & $\begin{array}{c}0.057 \\
0\end{array}$ \\
\hline secondary schools & & $(0.259)$ & & $(0.268)$ & & $(0.397)$ & & $(0.444)$ \\
\hline Mixed secondary schools per & & 3.369 & & 4.821 & & 3.611 & & 4.234 \\
\hline 1000 & & (2.617) & & (3.103) & & (2.838) & & (3.154) \\
\hline $\begin{array}{l}\text { Parent's schooling * mixed } \\
\text { secondary schools }\end{array}$ & & $\begin{array}{c}0.076 \\
(0.165)\end{array}$ & & $\begin{array}{l}-0.035 \\
(0.165)\end{array}$ & & $\begin{array}{c}0.331 \\
(0.225)\end{array}$ & & $\begin{array}{c}0.322 \\
(0.263)\end{array}$ \\
\hline Year of birth FE? & Yes & Yes & Yes & Yes & Yes & Yes & Yes & Yes \\
\hline Sub-district of birth FE? & Yes & Yes & Yes & Yes & Yes & Yes & Yes & Yes \\
\hline $\begin{array}{l}\text { Governorate of birth FE * } \\
\text { Year of birth FE? }\end{array}$ & No & No & Yes & Yes & No & No & Yes & Yes \\
\hline Observations & 2517 & 2517 & 2517 & 2517 & 2517 & 2517 & 2517 & 2517 \\
\hline Adjusted $R^{2}$ & 0.083 & 0.086 & 0.078 & 0.080 & 0.097 & 0.103 & 0.092 & 0.098 \\
\hline
\end{tabular}

Source: The 2010 Jordan Labor Market Panel Survey matched to the 2010 Jordan school census. The sample is restricted to individuals who are aged 25 to 70 years in 2010, are born in Jordan, and with nonmissing values on age, sub-district of birth, years of schooling, father's schooling, mother's schooling, and the local supply of schools in the sub-district of birth. The sample is further restricted to individuals who have at least basic education.

Notes: ${ }^{*} \mathrm{p}<0.10,{ }^{* *} \mathrm{p}<0.05$, and ${ }^{* * *} \mathrm{p}<0.01$. Standard errors clustered at the sub-district of birth level are in parentheses. 


\section{APPENDIX FOR ONLINE PUBLICATION}

TABLE A1

\section{Intergenerational Educational Mobility and Local Supply of Public Schools - Excluding Movers}

\section{A. Male Sample}

\begin{tabular}{|c|c|c|c|c|c|c|c|c|}
\hline & \multicolumn{4}{|c|}{ Males-Fathers } & \multicolumn{4}{|c|}{ Males-Mothers } \\
\hline & (1) & (2) & (3) & (4) & (5) & (6) & (7) & $(8)$ \\
\hline Parent's schooling & $\begin{array}{l}0.290^{* * *} \\
(0.020)\end{array}$ & $\begin{array}{l}0.300^{* * *} \\
(0.023)\end{array}$ & $\begin{array}{l}0.286^{* * *} \\
(0.021)\end{array}$ & $\begin{array}{l}0.290^{* * *} \\
(0.024)\end{array}$ & $\begin{array}{l}0.307^{* * *} \\
(0.041)\end{array}$ & $\begin{array}{l}0.299^{* * *} \\
(0.043)\end{array}$ & $\begin{array}{l}0.301^{* * *} \\
(0.042)\end{array}$ & $\begin{array}{l}0.275^{* * *} \\
(0.042)\end{array}$ \\
\hline Total basic schools per 1000 & $\begin{array}{l}3.536^{* * *} \\
(0.933)\end{array}$ & & $\begin{array}{l}1.634^{*} \\
(0.844)\end{array}$ & & $\begin{array}{l}3.161^{* * *} \\
(0.893)\end{array}$ & & $\begin{array}{l}1.277^{*} \\
(0.752)\end{array}$ & \\
\hline $\begin{array}{l}\text { Parent's schooling * total } \\
\text { basic schools }\end{array}$ & $\begin{array}{c}-0.370^{* * *} \\
(0.118)\end{array}$ & & $\begin{array}{l}-0.337^{* *} \\
(0.130)\end{array}$ & & $\begin{array}{l}-0.382^{* *} \\
(0.189)\end{array}$ & & $\begin{array}{l}-0.337^{*} \\
(0.199)\end{array}$ & \\
\hline Total secondary schools per & $4.833^{* * *}$ & & $4.043^{* * *}$ & & $4.824^{* * *}$ & & $4.111^{* * *}$ & \\
\hline 1000 & $(1.081)$ & & $(1.276)$ & & $(1.066)$ & & $(1.280)$ & \\
\hline $\begin{array}{l}\text { Parent's schooling * total } \\
\text { secondary schools }\end{array}$ & $\begin{array}{c}0.102 \\
(0.129)\end{array}$ & & $\begin{array}{c}0.101 \\
(0.136)\end{array}$ & & $\begin{array}{c}0.192 \\
(0.185)\end{array}$ & & $\begin{array}{c}0.136 \\
(0.185)\end{array}$ & \\
\hline Boys' basic schools per 1000 & & $\begin{array}{c}3.263 \\
(2.171)\end{array}$ & & $\begin{array}{c}0.451 \\
(2.248)\end{array}$ & & $\begin{array}{c}2.284 \\
(2.075)\end{array}$ & & $\begin{array}{l}-0.922 \\
(2.108)\end{array}$ \\
\hline $\begin{array}{l}\text { Parent's schooling * boys' } \\
\text { basic schools }\end{array}$ & & $\begin{array}{l}-0.592^{* *} \\
(0.244)\end{array}$ & & $\begin{array}{l}-0.496^{*} \\
(0.273)\end{array}$ & & $\begin{array}{l}-0.337 \\
(0.350)\end{array}$ & & $\begin{array}{l}-0.070 \\
(0.369)\end{array}$ \\
\hline Mixed basic schools per 1000 & & $\begin{array}{l}3.473^{* * *} \\
(1.258)\end{array}$ & & $\begin{array}{c}1.811 \\
(1.153)\end{array}$ & & $\begin{array}{l}3.418^{* * *} \\
(1.221)\end{array}$ & & $\begin{array}{l}1.920^{*} \\
(1.089)\end{array}$ \\
\hline $\begin{array}{l}\text { Parent's schooling * mixed } \\
\text { basic schools }\end{array}$ & & $\begin{array}{l}-0.263 \\
(0.195)\end{array}$ & & $\begin{array}{l}-0.251 \\
(0.205)\end{array}$ & & $\begin{array}{l}-0.414^{*} \\
(0.231)\end{array}$ & & $\begin{array}{l}-0.475^{*} \\
(0.244)\end{array}$ \\
\hline Boys' secondary schools per & & $4.208^{*}$ & & 2.180 & & $4.201^{*}$ & & 2.280 \\
\hline 1000 & & $(2.276)$ & & $(2.344)$ & & $(2.304)$ & & $(2.265)$ \\
\hline $\begin{array}{l}\text { Parent's schooling * boys' } \\
\text { secondary schools }\end{array}$ & & $\begin{array}{c}0.032 \\
(0.269)\end{array}$ & & $\begin{array}{c}0.220 \\
(0.309)\end{array}$ & & $\begin{array}{c}0.435 \\
(0.448)\end{array}$ & & $\begin{array}{c}0.732 \\
(0.467)\end{array}$ \\
\hline Mixed secondary schools per & & $5.593^{* *}$ & & $6.253^{* *}$ & & $5.672^{* *}$ & & $6.355^{* *}$ \\
\hline 1000 & & $(2.324)$ & & $(2.663)$ & & (2.417) & & $(2.891)$ \\
\hline $\begin{array}{l}\text { Parent's schooling * mixed } \\
\text { secondary schools }\end{array}$ & & $\begin{array}{c}0.175 \\
(0.311)\end{array}$ & & $\begin{array}{l}-0.097 \\
(0.329)\end{array}$ & & $\begin{array}{l}-0.081 \\
(0.418)\end{array}$ & & $\begin{array}{l}-0.536 \\
(0.464)\end{array}$ \\
\hline Year of birth FE? & Yes & Yes & Yes & Yes & Yes & Yes & Yes & Yes \\
\hline Sub-district of birth FE? & Yes & Yes & Yes & Yes & Yes & Yes & Yes & Yes \\
\hline $\begin{array}{l}\text { Governorate of birth FE * } \\
\text { Year of birth FE? }\end{array}$ & No & No & Yes & Yes & No & No & Yes & Yes \\
\hline Observations & 3758 & 3758 & 3758 & 3758 & 3758 & 3758 & 3758 & 3758 \\
\hline Adjusted $R^{2}$ & 0.200 & 0.199 & 0.216 & 0.216 & 0.179 & 0.178 & 0.194 & 0.193 \\
\hline
\end{tabular}




\section{B. Female Sample}

\begin{tabular}{|c|c|c|c|c|c|c|c|c|}
\hline & \multicolumn{4}{|c|}{ Females-Fathers } & \multicolumn{4}{|c|}{ Females-Mothers } \\
\hline & (1) & $(2)$ & (3) & (4) & (5) & (6) & (7) & (8) \\
\hline Parent's schooling & $0.277^{* * *}$ & $0.376^{* * *}$ & $0.265^{* * *}$ & $0.340^{* * *}$ & $0.334^{* * *}$ & $0.403^{* * *}$ & $0.338^{* * *}$ & $0.371^{* * *}$ \\
\hline Total basic schools per 1000 & $\begin{array}{c}(0.024) \\
9.470^{* * *} \\
(1.916)\end{array}$ & $(0.041)$ & $\begin{array}{l}(0.023) \\
5.145^{* * *} \\
(1.386)\end{array}$ & $(0.036)$ & $\begin{array}{l}(0.034) \\
8.226^{* * *} \\
(1.852)\end{array}$ & $(0.062)$ & $\begin{array}{c}(0.036) \\
3.830^{* * *} \\
(1.430)\end{array}$ & $(0.054)$ \\
\hline Parent's schooling * total & $-0.925^{* * *}$ & & $-0.740^{* * * *}$ & & $-0.801^{* * *}$ & & $-0.604^{* * *}$ & \\
\hline basic schools & $(0.226)$ & & $(0.196)$ & & $(0.268)$ & & $(0.280)$ & \\
\hline Total secondary schools per & -0.825 & & -0.714 & & 0.350 & & 0.527 & \\
\hline 1000 & (2.398) & & (2.104) & & (2.538) & & $(2.123)$ & \\
\hline $\begin{array}{l}\text { Parent's schooling * total } \\
\text { secondary schools }\end{array}$ & $\begin{array}{l}0.905^{* * *} \\
(0.203)\end{array}$ & & $\begin{array}{l}0.675^{* * *} \\
(0.188)\end{array}$ & & $\begin{array}{l}0.596^{* * *} \\
(0.204)\end{array}$ & & $\begin{array}{c}0.309 \\
(0.283)\end{array}$ & \\
\hline Girls' basic schools per 1000 & & $\begin{array}{c}-9.602 \\
(10.508)\end{array}$ & & $\begin{array}{l}-10.412 \\
(10.053)\end{array}$ & & $\begin{array}{l}-18.086 \\
(11.296)\end{array}$ & & $\begin{array}{l}-16.554 \\
(10.608)\end{array}$ \\
\hline Parent's schooling * girls' & & $-2.307^{* * *}$ & & $-1.643^{* * *}$ & & -0.958 & & -0.158 \\
\hline Mixed basic schools per 1000 & & $\begin{array}{l}8.456^{* * *} \\
(1.606)\end{array}$ & & $\begin{array}{l}5.196^{* * *} \\
(1.455)\end{array}$ & & $\begin{array}{l}7.830^{* * *} \\
(1.639)\end{array}$ & & $\begin{array}{l}4.290^{* * *} \\
(1.532)\end{array}$ \\
\hline $\begin{array}{l}\text { Parent's schooling * mixed } \\
\text { basic schools }\end{array}$ & & $\begin{array}{c}-0.731^{* * *} \\
(0.207)\end{array}$ & & $\begin{array}{c}-0.629^{* * *} \\
(0.190)\end{array}$ & & $\begin{array}{c}-0.757^{* * *} \\
(0.254)\end{array}$ & & $\begin{array}{l}-0.620^{* *} \\
(0.252)\end{array}$ \\
\hline Girls' secondary schools per & & $-8.083^{*}$ & & -8.509 & & $-9.074^{* *}$ & & -9.122 \\
\hline 1000 & & (4.373) & & (5.516) & & (4.325) & & $(5.734)$ \\
\hline Parent's schooling * girls' & & $-0.786^{* *}$ & & $-0.796^{*}$ & & $-1.507^{* *}$ & & $-1.548^{* *}$ \\
\hline secondary schools & & $(0.394)$ & & $(0.407)$ & & $(0.612)$ & & $(0.701)$ \\
\hline Mixed secondary schools per & & 1.556 & & 1.565 & & 3.057 & & 2.994 \\
\hline 1000 & & (2.935) & & (2.915) & & (3.095) & & (2.939) \\
\hline $\begin{array}{l}\text { Parent's schooling * mixed } \\
\text { secondary schools }\end{array}$ & & $\begin{array}{l}1.257^{* * *} \\
(0.262)\end{array}$ & & $\begin{array}{l}1.119^{* * *} \\
(0.263)\end{array}$ & & $\begin{array}{l}1.558^{* * *} \\
(0.386)\end{array}$ & & $\begin{array}{l}1.362^{* * *} \\
(0.392)\end{array}$ \\
\hline Year of birth FE? & Yes & Yes & Yes & Yes & Yes & Yes & Yes & Yes \\
\hline Sub-district of birth FE? & Yes & Yes & Yes & Yes & Yes & Yes & Yes & Yes \\
\hline $\begin{array}{l}\text { Governorate of birth FE * } \\
\text { Year of birth FE? }\end{array}$ & No & No & Yes & Yes & No & No & Yes & Yes \\
\hline Observations & 3760 & 3760 & 3760 & 3760 & 3760 & 3760 & 3760 & 3760 \\
\hline Adjusted $R^{2}$ & 0.441 & 0.450 & 0.458 & 0.462 & 0.426 & 0.433 & 0.448 & 0.451 \\
\hline
\end{tabular}

Source: The 2010 Jordan Labor Market Panel Survey matched to the 2010 Jordan school census. The sample is restricted to individuals who are aged 25 to 70 years in 2010, are born in Jordan, and with nonmissing values on age, sub-district of birth, years of schooling, father's schooling, mother's schooling, and the local supply of schools in the sub-district of birth. The sample excludes those who changed their place of residence between age 0 and 15 .

Notes: ${ }^{*} \mathrm{p}<0.10,{ }^{* *} \mathrm{p}<0.05$, and ${ }^{* * *} \mathrm{p}<0.01$. Standard errors clustered at the sub-district of birth level are in parentheses 
TABLE A2

\section{Intergenerational Educational Mobility and Local Supply of Public Schools - Excluding Refugees (Method I)}

\section{A. Male Sample}

\begin{tabular}{|c|c|c|c|c|c|c|c|c|}
\hline & \multicolumn{4}{|c|}{ Males-Fathers } & \multicolumn{4}{|c|}{ Males-Mothers } \\
\hline & (1) & (2) & (3) & (4) & (5) & (6) & (7) & (8) \\
\hline Parent's schooling & $\begin{array}{l}0.244^{* * *} \\
(0.021)\end{array}$ & $\begin{array}{l}0.262^{* * *} \\
(0.021)\end{array}$ & $\begin{array}{c}0.233^{* * *} \\
(0.026)\end{array}$ & $0.246^{* * *}$ & $0.260^{* * *}$ & $0.281^{* * *}$ & $\begin{array}{l}0.244^{* * *} \\
(0.47)\end{array}$ & $0.252^{* * *}$ \\
\hline Total basic schools per 1000 & $\begin{array}{l}2.478^{* * *} \\
(0.908)\end{array}$ & & $\begin{array}{c}0.274 \\
(0.869)\end{array}$ & & $\begin{array}{l}2.124^{* *} \\
(0.830)\end{array}$ & & $\begin{array}{c}0.106 \\
(0.776)\end{array}$ & \\
\hline Parent's schooling * total & $-0.261^{* *}$ & & -0.198 & & -0.317 & & -0.202 & \\
\hline basic schools & $(0.127)$ & & $(0.145)$ & & $(0.193)$ & & $(0.235)$ & \\
\hline Total secondary schools per & $3.794^{* * *}$ & & $3.491^{* * *}$ & & $3.626^{* * * *}$ & & $3.476^{* * *}$ & \\
\hline 1000 & $(1.020)$ & & $(1.160)$ & & $(0.955)$ & & (1.154) & \\
\hline $\begin{array}{l}\text { Parent's schooling * total } \\
\text { secondary schools }\end{array}$ & $\begin{array}{c}0.051 \\
(0.147)\end{array}$ & & $\begin{array}{c}0.056 \\
(0.175)\end{array}$ & & $\begin{array}{c}0.150 \\
(0.180)\end{array}$ & & $\begin{array}{c}0.044 \\
(0.223)\end{array}$ & \\
\hline Boys' basic schools per 1000 & & $\begin{array}{c}2.825 \\
(2.141)\end{array}$ & & $\begin{array}{c}0.331 \\
(2.485)\end{array}$ & & $\begin{array}{l}2.447 \\
(2.010)\end{array}$ & & $\begin{array}{l}-0.233 \\
(2.299)\end{array}$ \\
\hline $\begin{array}{l}\text { Parent's schooling * boys' } \\
\text { basic schools }\end{array}$ & & $\begin{array}{l}-0.453^{*} \\
(0.257)\end{array}$ & & $\begin{array}{l}-0.349 \\
(0.334)\end{array}$ & & $\begin{array}{l}-0.473 \\
(0.404)\end{array}$ & & $\begin{array}{l}-0.297 \\
(0.487)\end{array}$ \\
\hline Mixed basic schools per 1000 & & $\begin{array}{l}2.367^{* *} \\
(1.182)\end{array}$ & & $\begin{array}{c}0.343 \\
(1.196)\end{array}$ & & $\begin{array}{l}2.005^{*} \\
(1.091)\end{array}$ & & $\begin{array}{c}0.286 \\
(1.164)\end{array}$ \\
\hline $\begin{array}{l}\text { Parent's schooling * mixed } \\
\text { basic schools }\end{array}$ & & $\begin{array}{l}-0.190 \\
(0.180)\end{array}$ & & $\begin{array}{l}-0.149 \\
(0.199)\end{array}$ & & $\begin{array}{l}-0.229 \\
(0.235)\end{array}$ & & $\begin{array}{l}-0.165 \\
(0.292)\end{array}$ \\
\hline Boys' secondary schools per & & $3.915^{*}$ & & 4.094 & & 3.611 & & 3.897 \\
\hline 1000 & & $(2.284)$ & & $(2.833)$ & & $(2.197)$ & & $(2.720)$ \\
\hline $\begin{array}{l}\text { Parent's schooling * boys' } \\
\text { secondary schools }\end{array}$ & & $\begin{array}{l}-0.412 \\
(0.478)\end{array}$ & & $\begin{array}{l}-0.261 \\
(0.558)\end{array}$ & & $\begin{array}{l}-0.325 \\
(0.700)\end{array}$ & & $\begin{array}{l}-0.100 \\
(0.834)\end{array}$ \\
\hline Mixed secondary schools per & & 3.235 & & 2.563 & & 3.454 & & 3.047 \\
\hline 1000 & & (2.407) & & $(2.620)$ & & (2.328) & & $(2.672)$ \\
\hline $\begin{array}{l}\text { Parent's schooling * mixed } \\
\text { secondary schools }\end{array}$ & & $\begin{array}{c}0.686 \\
(0.498)\end{array}$ & & $\begin{array}{c}0.518 \\
(0.583)\end{array}$ & & $\begin{array}{c}0.631 \\
(0.585)\end{array}$ & & $\begin{array}{c}0.217 \\
(0.689)\end{array}$ \\
\hline Year of birth FE? & Yes & Yes & Yes & Yes & Yes & Yes & Yes & Yes \\
\hline Sub-district of birth FE? & Yes & Yes & Yes & Yes & Yes & Yes & Yes & Yes \\
\hline $\begin{array}{l}\text { Governorate of birth FE * } \\
\text { Year of birth FE? }\end{array}$ & No & No & Yes & Yes & No & No & Yes & Yes \\
\hline Observations & 2325 & 2325 & 2325 & 2325 & 2325 & 2325 & 2325 & 2325 \\
\hline Adjusted $R^{2}$ & 0.243 & 0.243 & 0.266 & 0.265 & 0.230 & 0.229 & 0.251 & 0.249 \\
\hline
\end{tabular}




\section{B. Female Sample}

\begin{tabular}{|c|c|c|c|c|c|c|c|c|}
\hline & \multicolumn{4}{|c|}{ Females-Fathers } & \multicolumn{4}{|c|}{ Females-Mothers } \\
\hline & (1) & (2) & (3) & (4) & (5) & (6) & (7) & (8) \\
\hline Parent's schooling & $\begin{array}{l}0.307^{* * *} \\
(0.027)\end{array}$ & $\begin{array}{l}0.376^{* * *} \\
(0.057)\end{array}$ & $\begin{array}{l}0.298^{* * *} \\
(0.033)\end{array}$ & $\begin{array}{l}0.353^{* * *} \\
(0.051)\end{array}$ & $\begin{array}{c}0.374^{* * *} \\
(0.053)\end{array}$ & $\begin{array}{l}0.406^{* * *} \\
(0.079)\end{array}$ & $\begin{array}{l}0.367^{* * *} \\
(0.063)\end{array}$ & $\begin{array}{c}0.362^{* * *} \\
(0.076)\end{array}$ \\
\hline Total basic schools per 1000 & $\begin{array}{l}6.718^{* * *} \\
(1.976)\end{array}$ & & $\begin{array}{l}4.492^{* * * *} \\
(1.563)\end{array}$ & & $\begin{array}{l}5.599^{* * *} \\
(2.039)\end{array}$ & & $\begin{array}{l}3.543^{* *} \\
(1.655)\end{array}$ & \\
\hline Parent's schooling * total & $-0.838^{* * * *}$ & & $-0.697^{* * *}$ & & $-0.803^{* * *}$ & & $-0.739^{* *}$ & \\
\hline basic schools & $(0.216)$ & & $(0.221)$ & & $(0.295)$ & & $(0.333)$ & \\
\hline Total secondary schools per & -1.902 & & -2.411 & & -1.090 & & -1.388 & \\
\hline 1000 & $(2.229)$ & & $(2.573)$ & & $(2.296)$ & & $(2.645)$ & \\
\hline $\begin{array}{l}\text { Parent's schooling * total } \\
\text { secondary schools }\end{array}$ & $\begin{array}{l}0.730^{* * *} \\
(0.195)\end{array}$ & & $\begin{array}{l}0.535^{* *} \\
(0.232)\end{array}$ & & $\begin{array}{l}0.453^{* * *} \\
(0.205)\end{array}$ & & $\begin{array}{c}0.399 \\
(0.296)\end{array}$ & \\
\hline Girls' basic schools per 1000 & & $\begin{array}{l}-3.304 \\
(8.630)\end{array}$ & & $\begin{array}{l}-5.241 \\
(9.607)\end{array}$ & & $\begin{array}{r}-10.451 \\
(9.804)\end{array}$ & & $\begin{array}{c}-9.169 \\
(10.494)\end{array}$ \\
\hline Parent's schooling * girls' & & $-1.974^{* * *}$ & & $-1.251^{*}$ & & -0.356 & & 0.625 \\
\hline basic schools & & $(0.689)$ & & $(0.664)$ & & $(1.071)$ & & $(1.071)$ \\
\hline Mixed basic schools per 1000 & & $\begin{array}{c}6.540^{* * *} \\
(1.843)\end{array}$ & & $\begin{array}{l}4.497^{* * *} \\
(1.585)\end{array}$ & & $\begin{array}{l}5.765^{* * *} \\
(2.008)\end{array}$ & & $\begin{array}{l}3.725^{* *} \\
(1.668)\end{array}$ \\
\hline Parent's schooling * mixed & & $-0.738^{* * *}$ & & $-0.651^{* * * *}$ & & $-0.814^{* * *}$ & & $-0.787^{* * *}$ \\
\hline $\begin{array}{l}\text { basic schools } \\
\text { Girls' secondary schools per }\end{array}$ & & $\begin{array}{l}(0.210) \\
-5.685\end{array}$ & & $\begin{array}{l}(0.209) \\
-2.915\end{array}$ & & $\begin{array}{l}(0.267) \\
-6.351^{*}\end{array}$ & & $\begin{array}{l}(0.290) \\
-3.275\end{array}$ \\
\hline 1000 & & (3.696) & & $(4.669)$ & & (3.658) & & $(4.910)$ \\
\hline Parent's schooling * girls' & & -0.397 & & -0.657 & & $-1.126^{*}$ & & -0.898 \\
\hline secondary schools & & $(0.428)$ & & $(0.522)$ & & (0.639) & & $(0.838)$ \\
\hline Mixed secondary schools per & & -0.472 & & -2.334 & & 0.702 & & -1.092 \\
\hline 1000 & & $(2.871)$ & & (3.218) & & $(2.951)$ & & (3.348) \\
\hline $\begin{array}{l}\text { Parent's schooling * mixed } \\
\text { secondary schools }\end{array}$ & & $\begin{array}{l}1.032^{* * *} \\
(0.228)\end{array}$ & & $\begin{array}{l}0.998^{* * *} \\
(0.267)\end{array}$ & & $\begin{array}{l}1.361^{* * *} \\
(0.383)\end{array}$ & & $\begin{array}{l}1.292^{* * *} \\
(0.433)\end{array}$ \\
\hline Year of birth FE? & Yes & Yes & Yes & Yes & Yes & Yes & Yes & Yes \\
\hline Sub-district of birth FE? & Yes & Yes & Yes & Yes & Yes & Yes & Yes & Yes \\
\hline $\begin{array}{l}\text { Governorate of birth FE * } \\
\text { Year of birth FE? }\end{array}$ & No & No & Yes & Yes & No & No & Yes & Yes \\
\hline Observations & 2284 & 2284 & 2284 & 2284 & 2284 & 2284 & 2284 & 2284 \\
\hline Adjusted $R^{2}$ & 0.492 & 0.496 & 0.506 & 0.507 & 0.475 & 0.479 & 0.493 & 0.494 \\
\hline
\end{tabular}

Source: The 2010 Jordan Labor Market Panel Survey matched to the 2010 Jordan school census. The sample is restricted to individuals who are aged 25 to 70 years in 2010, are born in Jordan, and with nonmissing values on age, sub-district of birth, years of schooling, father's schooling, mother's schooling, and the local supply of schools in the sub-district of birth. The sample further excludes those born in subdistricts where the percentage of individuals below 36 of age in the sample who were ever enrolled (or are currently enrolled) in an UNRWA school exceeds 10 percent.

Notes: ${ }^{*} \mathrm{p}<0.10,{ }^{* *} \mathrm{p}<0.05$, and ${ }^{* * *} \mathrm{p}<0.01$. Standard errors clustered at the sub-district of birth level are in parentheses. 
TABLE A3

\section{Intergenerational Educational Mobility and Local Supply of Public Schools - Excluding Refugees (Method II)}

\section{A. Male Sample}

\begin{tabular}{|c|c|c|c|c|c|c|c|c|}
\hline & \multicolumn{4}{|c|}{ Males-Fathers } & \multicolumn{4}{|c|}{ Males-Mothers } \\
\hline & (1) & (2) & (3) & (4) & (5) & (6) & (7) & (8) \\
\hline Parent's schooling & $\begin{array}{l}0.280^{* * *} \\
(0.018)\end{array}$ & $\begin{array}{l}0.298^{* * *} \\
(0.021)\end{array}$ & $\begin{array}{l}0.278^{* * *} \\
(0.019)\end{array}$ & $\begin{array}{l}0.288^{* * *} \\
(0.021)\end{array}$ & $\begin{array}{l}0.318^{* * *} \\
(0.037)\end{array}$ & $\begin{array}{l}0.330^{* * *} \\
(0.041)\end{array}$ & $\begin{array}{l}0.324^{* * *} \\
(0.040)\end{array}$ & $\begin{array}{l}0.320^{* * *} \\
(0.042)\end{array}$ \\
\hline Total basic schools per 1000 & $\begin{array}{l}3.195^{* * *} \\
(0.876)\end{array}$ & & $\begin{array}{l}1.404^{*} \\
(0.812)\end{array}$ & & $\begin{array}{l}3.064^{* * *} \\
(0.855)\end{array}$ & & $\begin{array}{l}1.315^{*} \\
(0.740)\end{array}$ & \\
\hline Parent's schooling * total & $-0.278^{* *}$ & & $-0.249^{*}$ & & $-0.353^{*}$ & & $-0.338^{*}$ & \\
\hline basic schools & $(0.122)$ & & $(0.129)$ & & $(0.188)$ & & $(0.201)$ & \\
\hline Total secondary schools per & $4.917^{* * * *}$ & & $4.321^{* * * *}$ & & $4.894^{\text {*a* }}$ & & $4.352^{* * * *}$ & \\
\hline 1000 & $(1.120)$ & & $(1.252)$ & & $(1.144)$ & & $(1.289)$ & \\
\hline $\begin{array}{l}\text { Parent's schooling * total } \\
\text { secondary schools }\end{array}$ & $\begin{array}{c}0.002 \\
(0.141)\end{array}$ & & $\begin{array}{c}0.003 \\
(0.145)\end{array}$ & & $\begin{array}{c}0.116 \\
(0.189)\end{array}$ & & $\begin{array}{c}0.061 \\
(0.192)\end{array}$ & \\
\hline Boys' basic schools per 1000 & & $\begin{array}{c}2.459 \\
(2.081)\end{array}$ & & $\begin{array}{l}-0.288 \\
(2.253)\end{array}$ & & $\begin{array}{l}1.780 \\
(2.005)\end{array}$ & & $\begin{array}{l}-1.053 \\
(2.136)\end{array}$ \\
\hline Parent's schooling * boys' & & $-0.469^{*}$ & & -0.342 & & -0.381 & & -0.225 \\
\hline basic schools & & $(0.244)$ & & $(0.284)$ & & $(0.366)$ & & $(0.407)$ \\
\hline Mixed basic schools per 1000 & & $\begin{array}{l}3.412^{* * *} \\
(1.146)\end{array}$ & & $\begin{array}{l}1.889^{*} \\
(1.127)\end{array}$ & & $\begin{array}{l}3.507^{* * *} \\
(1.145)\end{array}$ & & $\begin{array}{l}2.054^{*} \\
(1.069)\end{array}$ \\
\hline $\begin{array}{l}\text { Parent's schooling * mixed } \\
\text { basic schools }\end{array}$ & & $\begin{array}{l}-0.203 \\
(0.175)\end{array}$ & & $\begin{array}{l}-0.212 \\
(0.182)\end{array}$ & & $\begin{array}{l}-0.324 \\
(0.221)\end{array}$ & & $\begin{array}{l}-0.378 \\
(0.248)\end{array}$ \\
\hline Boys' secondary schools per & & $4.820^{*}$ & & 3.352 & & $4.669^{*}$ & & 3.349 \\
\hline 1000 & & $(2.482)$ & & $(2.578)$ & & $(2.461)$ & & (2.499) \\
\hline $\begin{array}{l}\text { Parent's schooling * boys' } \\
\text { secondary schools }\end{array}$ & & $\begin{array}{l}-0.411 \\
(0.468)\end{array}$ & & $\begin{array}{l}-0.212 \\
(0.507)\end{array}$ & & $\begin{array}{l}-0.256 \\
(0.674)\end{array}$ & & $\begin{array}{c}0.040 \\
(0.716)\end{array}$ \\
\hline Mixed secondary schools per & & $4.774^{*}$ & & $5.297^{*}$ & & $5.100^{* *}$ & & $5.536^{*}$ \\
\hline 1000 & & $(2.415)$ & & $(2.749)$ & & $(2.392)$ & & $(2.813)$ \\
\hline $\begin{array}{l}\text { Parent's schooling * mixed } \\
\text { secondary schools }\end{array}$ & & $\begin{array}{c}0.550 \\
(0.496)\end{array}$ & & $\begin{array}{c}0.279 \\
(0.535)\end{array}$ & & $\begin{array}{c}0.480 \\
(0.568)\end{array}$ & & $\begin{array}{c}0.041 \\
(0.628)\end{array}$ \\
\hline Year of birth FE? & Yes & Yes & Yes & Yes & Yes & Yes & Yes & Yes \\
\hline Sub-district of birth FE? & Yes & Yes & Yes & Yes & Yes & Yes & Yes & Yes \\
\hline $\begin{array}{l}\text { Governorate of birth FE * } \\
\text { Year of birth FE? }\end{array}$ & No & No & Yes & Yes & No & No & Yes & Yes \\
\hline Observations & 3968 & 3968 & 3968 & 3968 & 3968 & 3968 & 3968 & 3968 \\
\hline Adjusted $R^{2}$ & 0.194 & 0.194 & 0.209 & 0.209 & 0.179 & 0.178 & 0.194 & 0.193 \\
\hline
\end{tabular}




\section{B. Female Sample}

\begin{tabular}{|c|c|c|c|c|c|c|c|c|}
\hline & \multicolumn{4}{|c|}{ Females-Fathers } & \multicolumn{4}{|c|}{ Females-Mothers } \\
\hline & (1) & (2) & (3) & (4) & (5) & (6) & (7) & (8) \\
\hline Parent's schooling & $\begin{array}{l}0.285^{* * *} \\
(0.024)\end{array}$ & $\begin{array}{c}0.379^{* * *} \\
(0.042)\end{array}$ & $\begin{array}{l}0.274^{* * *} \\
(0.023)\end{array}$ & $\begin{array}{l}0.345^{* * *} \\
(0.037)\end{array}$ & $\begin{array}{l}0.344^{* * *} \\
(0.037)\end{array}$ & $\begin{array}{l}0.409^{* * *} \\
(0.062)\end{array}$ & $\begin{array}{l}0.345^{* * *} \\
(0.040)\end{array}$ & $\begin{array}{l}0.365^{* * *} \\
(0.058)\end{array}$ \\
\hline Total basic schools per 1000 & $\begin{array}{l}9.387^{* * *} \\
(1.925)\end{array}$ & & $\begin{array}{l}5.370^{* * *} \\
(1.355)\end{array}$ & & $\begin{array}{l}8.245^{* * *} \\
(1.878)\end{array}$ & & $\begin{array}{l}4.182^{* * *} \\
(1.403)\end{array}$ & \\
\hline Parent's schooling * total & $-0.955^{* * *}$ & & $-0.780^{* * * *}$ & & $-0.896^{* * *}$ & & $-0.740^{* *}$ & \\
\hline basic schools & $(0.218)$ & & $(0.194)$ & & $(0.271)$ & & $(0.294)$ & \\
\hline Total secondary schools per & -0.583 & & -0.575 & & 0.704 & & 0.733 & \\
\hline 1000 & $(2.376)$ & & $(2.235)$ & & $(2.523)$ & & $(2.301)$ & \\
\hline $\begin{array}{l}\text { Parent's schooling * total } \\
\text { secondary schools }\end{array}$ & $\begin{array}{l}0.950^{* * *} \\
(0.194)\end{array}$ & & $\begin{array}{l}0.715^{* * *} \\
(0.188)\end{array}$ & & $\begin{array}{c}0.666^{* * *} \\
(0.227)\end{array}$ & & $\begin{array}{c}0.447 \\
(0.305)\end{array}$ & \\
\hline Girls' basic schools per 1000 & & $\begin{array}{l}-10.232 \\
(10.321)\end{array}$ & & $\begin{array}{l}-9.839 \\
(9.811)\end{array}$ & & $\begin{array}{l}-18.522 \\
(11.252)\end{array}$ & & $\begin{array}{l}-15.442 \\
(10.308)\end{array}$ \\
\hline Parent's schooling * girls' & & $-2.290^{* * *}$ & & $-1.685^{* * * *}$ & & $-1.138^{*}$ & & -0.343 \\
\hline $\begin{array}{l}\text { basic schools } \\
\text { Mixed basic schools per } 1000\end{array}$ & & $\begin{array}{c}(0.423) \\
8.447^{* * *}\end{array}$ & & $\begin{array}{l}(0.426) \\
5.413^{* * *} \\
(1.399)\end{array}$ & & $\begin{array}{l}(0.633) \\
7.904^{* * *} \\
(1.648)\end{array}$ & & $\begin{array}{l}(0.677) \\
4.669^{* * *} \\
(1.479)\end{array}$ \\
\hline $\begin{array}{l}\text { Parent's schooling * mixed } \\
\text { basic schools }\end{array}$ & & $\begin{array}{l}-0.755^{* * *} \\
(0.207)\end{array}$ & & $\begin{array}{l}-0.650^{* * * *} \\
(0.194)\end{array}$ & & $\begin{array}{l}-0.829^{* * *} \\
(0.266)\end{array}$ & & $\begin{array}{l}-0.738^{* * *} \\
(0.277)\end{array}$ \\
\hline Girls' secondary schools per & & $-6.182^{*}$ & & -4.979 & & $-6.755^{*}$ & & -5.361 \\
\hline 1000 & & $(3.516)$ & & $(4.210)$ & & (3.499) & & $(4.417)$ \\
\hline Parent's schooling * girls' & & -0.504 & & -0.539 & & $-1.178^{*}$ & & -0.955 \\
\hline secondary schools & & $(0.443)$ & & $(0.463)$ & & $(0.653)$ & & $(0.723)$ \\
\hline Mixed secondary schools per & & 0.907 & & 0.490 & & 2.374 & & 1.972 \\
\hline 1000 & & (2.979) & & (3.119) & & (3.065) & & (3.149) \\
\hline $\begin{array}{l}\text { Parent's schooling * mixed } \\
\text { secondary schools }\end{array}$ & & $\begin{array}{l}1.155^{* * *} \\
(0.258)\end{array}$ & & $\begin{array}{l}1.024^{* * *} \\
(0.258)\end{array}$ & & $\begin{array}{l}1.441^{* * *} \\
(0.409)\end{array}$ & & $\begin{array}{l}1.262^{* * *} \\
(0.418)\end{array}$ \\
\hline Year of birth FE? & Yes & Yes & Yes & Yes & Yes & Yes & Yes & Yes \\
\hline Sub-district of birth FE? & Yes & Yes & Yes & Yes & Yes & Yes & Yes & Yes \\
\hline $\begin{array}{l}\text { Governorate of birth FE * } \\
\text { Year of birth FE? }\end{array}$ & No & No & Yes & Yes & No & No & Yes & Yes \\
\hline Observations & 3963 & 3963 & 3963 & 3963 & 3963 & 3963 & 3963 & 3963 \\
\hline Adjusted $R^{2}$ & 0.435 & 0.442 & 0.454 & 0.457 & 0.418 & 0.425 & 0.443 & 0.445 \\
\hline
\end{tabular}

Source: The 2010 Jordan Labor Market Panel Survey matched to the 2010 Jordan school census. The sample is restricted to individuals who are aged 25 to 70 years in 2010, are born in Jordan, and with nonmissing values on age, sub-district of birth, years of schooling, father's schooling, mother's schooling, and the local supply of schools in the sub-district of birth. The sample further excludes those born in subdistricts where the percentage of UNRWA schools exceeds 10 percent of the total number of schools.

Notes: ${ }^{*} \mathrm{p}<0.10,{ }^{* *} \mathrm{p}<0.05$, and ${ }^{* * *} \mathrm{p}<0.01$. Standard errors clustered at the sub-district of birth level are in parentheses. 
TABLE A4

\section{Intergenerational Educational Mobility and Local Supply of Public Schools - HH Heads and Spouses Only}

\section{A. Male Sample}

\begin{tabular}{|c|c|c|c|c|c|c|c|c|}
\hline & \multicolumn{4}{|c|}{ Males-Fathers } & \multicolumn{4}{|c|}{ Males-Mothers } \\
\hline & (1) & (2) & (3) & (4) & (5) & (6) & (7) & (8) \\
\hline Parent's schooling & $\begin{array}{l}0.288^{* * *} \\
(0.019)\end{array}$ & $\begin{array}{l}0.296^{* * *} \\
(0.021)\end{array}$ & $\begin{array}{l}0.279^{* * *} \\
(0.021)\end{array}$ & $\begin{array}{l}0.273^{* * *} \\
(0.025)\end{array}$ & $\begin{array}{l}0.343^{* * *} \\
(0.038)\end{array}$ & $\begin{array}{l}0.334^{* * *} \\
(0.044)\end{array}$ & $\begin{array}{l}0.335^{* * *} \\
(0.040)\end{array}$ & $\begin{array}{l}0.306^{* * *} \\
(0.047)\end{array}$ \\
\hline Total basic schools per 1000 & $\begin{array}{l}3.457^{* * *} \\
(0.888)\end{array}$ & & $\begin{array}{l}1.160 \\
(0.794)\end{array}$ & & $\begin{array}{l}3.128^{* * *} \\
(0.806)\end{array}$ & & $\begin{array}{c}0.849 \\
(0.738)\end{array}$ & \\
\hline Parent's schooling * total & $-0.452^{* * *}$ & & $-0.465^{* * *}$ & & $-0.698^{* *}$ & & $-0.692^{* *}$ & \\
\hline basic schools & $(0.168)$ & & $(0.166)$ & & $(0.288)$ & & $(0.327)$ & \\
\hline Total secondary schools per & $4.581^{* * *}$ & & $4.092^{* * *}$ & & $4.583^{* * *}$ & & $4.268^{* * * *}$ & \\
\hline 1000 & (1.092) & & (1.039) & & $(1.136)$ & & $(1.063)$ & \\
\hline $\begin{array}{l}\text { Parent's schooling * total } \\
\text { secondary schools }\end{array}$ & $\begin{array}{c}0.064 \\
(0.154)\end{array}$ & & $\begin{array}{c}0.187 \\
(0.145)\end{array}$ & & $\begin{array}{c}0.236 \\
(0.300)\end{array}$ & & $\begin{array}{c}0.287 \\
(0.294)\end{array}$ & \\
\hline Boys' basic schools per 1000 & & $\begin{array}{c}1.275 \\
(2.160)\end{array}$ & & $\begin{array}{l}-1.672 \\
(2.405)\end{array}$ & & $\begin{array}{c}0.000 \\
(2.195)\end{array}$ & & $\begin{array}{l}-2.963 \\
(2.368)\end{array}$ \\
\hline $\begin{array}{l}\text { Parent's schooling * boys' } \\
\text { basic schools }\end{array}$ & & $\begin{array}{l}-0.764^{* *} \\
(0.328)\end{array}$ & & $\begin{array}{l}-0.439 \\
(0.366)\end{array}$ & & $\begin{array}{l}-0.696 \\
(0.479)\end{array}$ & & $\begin{array}{l}-0.395 \\
(0.538)\end{array}$ \\
\hline Mixed basic schools per 1000 & & $\begin{array}{l}4.339^{* * *} \\
(1.168)\end{array}$ & & $\begin{array}{l}2.131^{* *} \\
(1.067)\end{array}$ & & $\begin{array}{c}4.389^{* * *} \\
(1.115)\end{array}$ & & $\begin{array}{l}2.242^{* *} \\
(1.050)\end{array}$ \\
\hline $\begin{array}{l}\text { Parent's schooling * mixed } \\
\text { basic schools }\end{array}$ & & $\begin{array}{l}-0.343 \\
(0.221)\end{array}$ & & $\begin{array}{l}-0.491^{* *} \\
(0.238)\end{array}$ & & $\begin{array}{l}-0.706^{*} \\
(0.370)\end{array}$ & & $\begin{array}{l}-0.837^{*} \\
(0.445)\end{array}$ \\
\hline Boys' secondary schools per & & $4.744^{*}$ & & 2.607 & & $4.689^{*}$ & & 2.737 \\
\hline 1000 & & (2.608) & & $(2.352)$ & & (2.597) & & $(2.392)$ \\
\hline $\begin{array}{l}\text { Parent's schooling * boys' } \\
\text { secondary schools }\end{array}$ & & $\begin{array}{c}0.307 \\
(0.386)\end{array}$ & & $\begin{array}{c}0.491 \\
(0.364)\end{array}$ & & $\begin{array}{c}0.842 \\
(0.659)\end{array}$ & & $\begin{array}{c}1.143 \\
(0.716)\end{array}$ \\
\hline Mixed secondary schools per & & $4.593^{*}$ & & $6.118^{* *}$ & & $4.713^{*}$ & & $6.436^{* *}$ \\
\hline 1000 & & $(2.641)$ & & $(2.538)$ & & $(2.754)$ & & (2.697) \\
\hline $\begin{array}{l}\text { Parent's schooling * mixed } \\
\text { secondary schools }\end{array}$ & & $\begin{array}{l}-0.328 \\
(0.551)\end{array}$ & & $\begin{array}{l}-0.296 \\
(0.500)\end{array}$ & & $\begin{array}{l}-0.672 \\
(0.791)\end{array}$ & & $\begin{array}{l}-0.906 \\
(0.964)\end{array}$ \\
\hline Year of birth FE? & Yes & Yes & Yes & Yes & Yes & Yes & Yes & Yes \\
\hline Sub-district of birth FE? & Yes & Yes & Yes & Yes & Yes & Yes & Yes & Yes \\
\hline $\begin{array}{l}\text { Governorate of birth FE * } \\
\text { Year of birth FE? }\end{array}$ & No & No & Yes & Yes & No & No & Yes & Yes \\
\hline Observations & 3271 & 3271 & 3271 & 3271 & 3271 & 3271 & 3271 & 3271 \\
\hline Adjusted $R^{2}$ & 0.187 & 0.187 & 0.200 & 0.199 & 0.167 & 0.167 & 0.179 & 0.179 \\
\hline
\end{tabular}




\section{B. Female Sample}

\begin{tabular}{|c|c|c|c|c|c|c|c|c|}
\hline & \multicolumn{4}{|c|}{ Females-Fathers } & \multicolumn{4}{|c|}{ Females-Mothers } \\
\hline & (1) & (2) & (3) & (4) & (5) & (6) & (7) & (8) \\
\hline Parent's schooling & $0.309^{* * *}$ & $0.430^{* * *}$ & $0.300^{* * *}$ & $0.400^{* * *}$ & $0.409^{* * *}$ & $0.513^{* * *}$ & $0.411^{* * *}$ & $0.455^{* * *}$ \\
\hline Total basic schools per 1000 & $\begin{array}{c}(0.031) \\
10.697^{* * *} \\
(2.101)\end{array}$ & $(0.047)$ & $\begin{array}{l}(0.029) \\
6.669^{* * *} \\
(1.724)\end{array}$ & $(0.044)$ & $\begin{array}{c}(0.043) \\
9.381^{* * *} \\
(1.970)\end{array}$ & & $\begin{array}{l}(0.046) \\
5.481^{* * *} \\
(1.647)\end{array}$ & \\
\hline Parent's schooling * total & $-1.218^{* * * *}$ & & $-1.063^{* * * *}$ & & $-1.229^{* * *}$ & & $-1.120^{* * * *}$ & \\
\hline basic schools & $(0.295)$ & & $(0.250)$ & & $(0.397)$ & & $(0.383)$ & \\
\hline Total secondary schools per & 0.329 & & 1.716 & & 1.868 & & 3.192 & \\
\hline 1000 & (2.484) & & $(2.584)$ & & (2.544) & & $(2.502)$ & \\
\hline $\begin{array}{l}\text { Parent's schooling * total } \\
\text { secondary schools }\end{array}$ & $\begin{array}{l}0.990^{* * *} \\
(0.207)\end{array}$ & & $\begin{array}{c}0.788^{* * *} \\
(0.248)\end{array}$ & & $\begin{array}{l}0.576^{* *} \\
(0.219)\end{array}$ & & $\begin{array}{c}0.420 \\
(0.325)\end{array}$ & \\
\hline Girls' basic schools per 1000 & & $\begin{array}{c}-5.439 \\
(10.823)\end{array}$ & & $\begin{array}{l}-6.229 \\
(9.865)\end{array}$ & & $\begin{array}{l}-14.515 \\
(11.517)\end{array}$ & & $\begin{array}{l}-12.947 \\
(10.198)\end{array}$ \\
\hline Parent's schooling * girls' & & $-3.167^{* * *}$ & & $-2.602^{* * *}$ & & $-2.115^{* * *}$ & & $-1.221^{*}$ \\
\hline $\begin{array}{l}\text { basic schools } \\
\text { Mixed basic schools per } 1000\end{array}$ & & $\begin{array}{c}(0.517) \\
9.394^{* * *} \\
(1.870)\end{array}$ & & $\begin{array}{l}(0.663) \\
6.789^{* * *} \\
(1810)\end{array}$ & & $\begin{array}{l}(0.663) \\
8.629^{* * *}\end{array}$ & & $\begin{array}{l}(0.633) \\
5.940^{* * *} \\
(1.791)\end{array}$ \\
\hline $\begin{array}{l}\text { Parent's schooling * mixed } \\
\text { basic schools }\end{array}$ & & $\begin{array}{c}-0.953^{* * *} \\
(0.270)\end{array}$ & & $\begin{array}{c}-0.846^{* * * *} \\
(0.250)\end{array}$ & & $\begin{array}{c}-1.061^{* * *} \\
(0.383)\end{array}$ & & $\begin{array}{c}-1.072^{* * *} \\
(0.385)\end{array}$ \\
\hline Girls' secondary schools per & & $-6.675^{*}$ & & -4.109 & & $-7.207^{*}$ & & -4.987 \\
\hline 1000 & & (3.774) & & (5.136) & & (3.626) & & $(5.359)$ \\
\hline Parent's schooling * girls' & & -0.572 & & -0.610 & & $-1.712^{* *}$ & & -1.119 \\
\hline secondary schools & & $(0.537)$ & & $(0.590)$ & & $(0.826)$ & & $(0.896)$ \\
\hline Mixed secondary schools per & & 3.019 & & 4.134 & & 4.755 & & $5.971^{*}$ \\
\hline 1000 & & $(3.170)$ & & (3.583) & & (3.134) & & (3.330) \\
\hline $\begin{array}{l}\text { Parent's schooling * mixed } \\
\text { secondary schools }\end{array}$ & & $\begin{array}{l}1.084^{* * * *} \\
(0.324)\end{array}$ & & $\begin{array}{l}0.943^{* *} \\
(0.400)\end{array}$ & & $\begin{array}{l}1.469^{* * *} \\
(0.517)\end{array}$ & & $\begin{array}{l}1.259^{* *} \\
(0.628)\end{array}$ \\
\hline Year of birth FE? & Yes & Yes & Yes & Yes & Yes & Yes & Yes & Yes \\
\hline Sub-district of birth FE? & Yes & Yes & Yes & Yes & Yes & Yes & Yes & Yes \\
\hline $\begin{array}{l}\text { Governorate of birth FE * } \\
\text { Year of birth FE? }\end{array}$ & No & No & Yes & Yes & No & No & Yes & Yes \\
\hline Observations & 3333 & 3333 & 3333 & 3333 & 3333 & 3333 & 3333 & 3333 \\
\hline Adjusted $R^{2}$ & 0.447 & 0.455 & 0.470 & 0.474 & 0.431 & 0.438 & 0.458 & 0.461 \\
\hline
\end{tabular}

Source: The 2010 Jordan Labor Market Panel Survey matched to the 2010 Jordan school census. The sample is restricted to individuals who are aged 25 to 70 years in 2010, are born in Jordan, and with nonmissing values on age, sub-district of birth, years of schooling, father's schooling, mother's schooling, and the local supply of schools in the sub-district of birth. The sample is further restricted to household heads or spouses

Notes: ${ }^{*} \mathrm{p}<0.10,{ }^{* *} \mathrm{p}<0.05$, and ${ }^{* * *} \mathrm{p}<0.01$. Standard errors clustered at the sub-district of birth level are in parentheses. 